
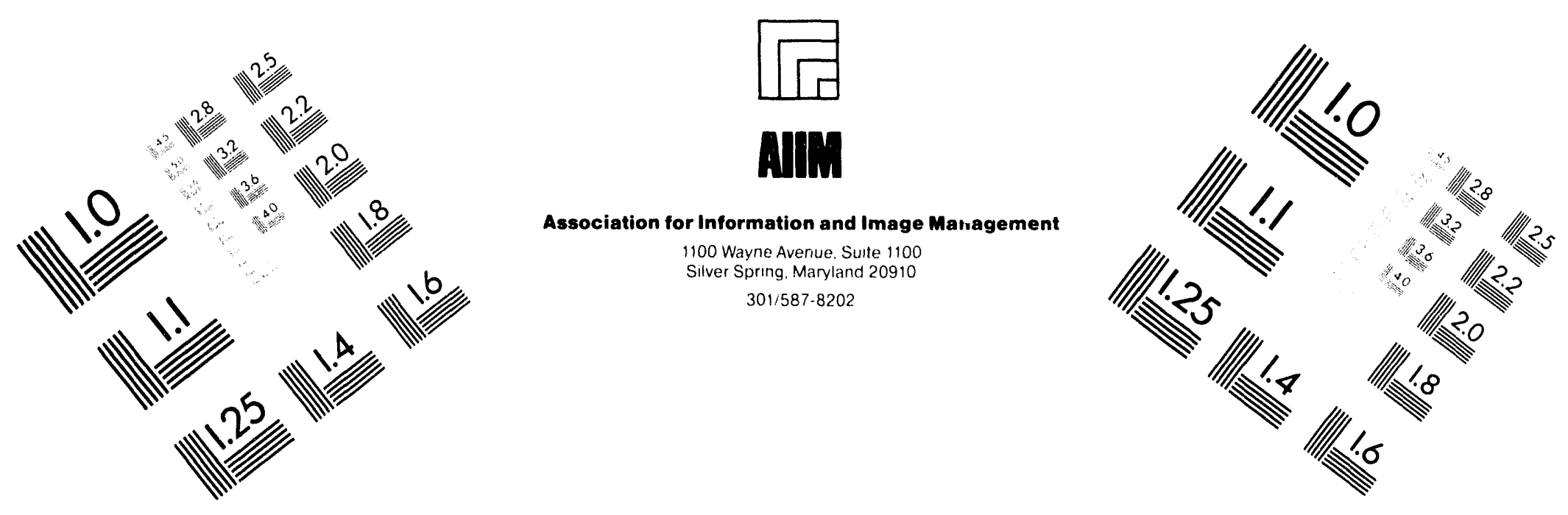

Centimeter

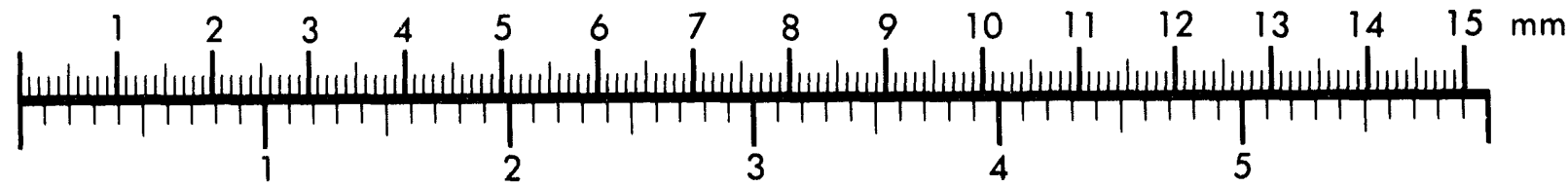
Inches
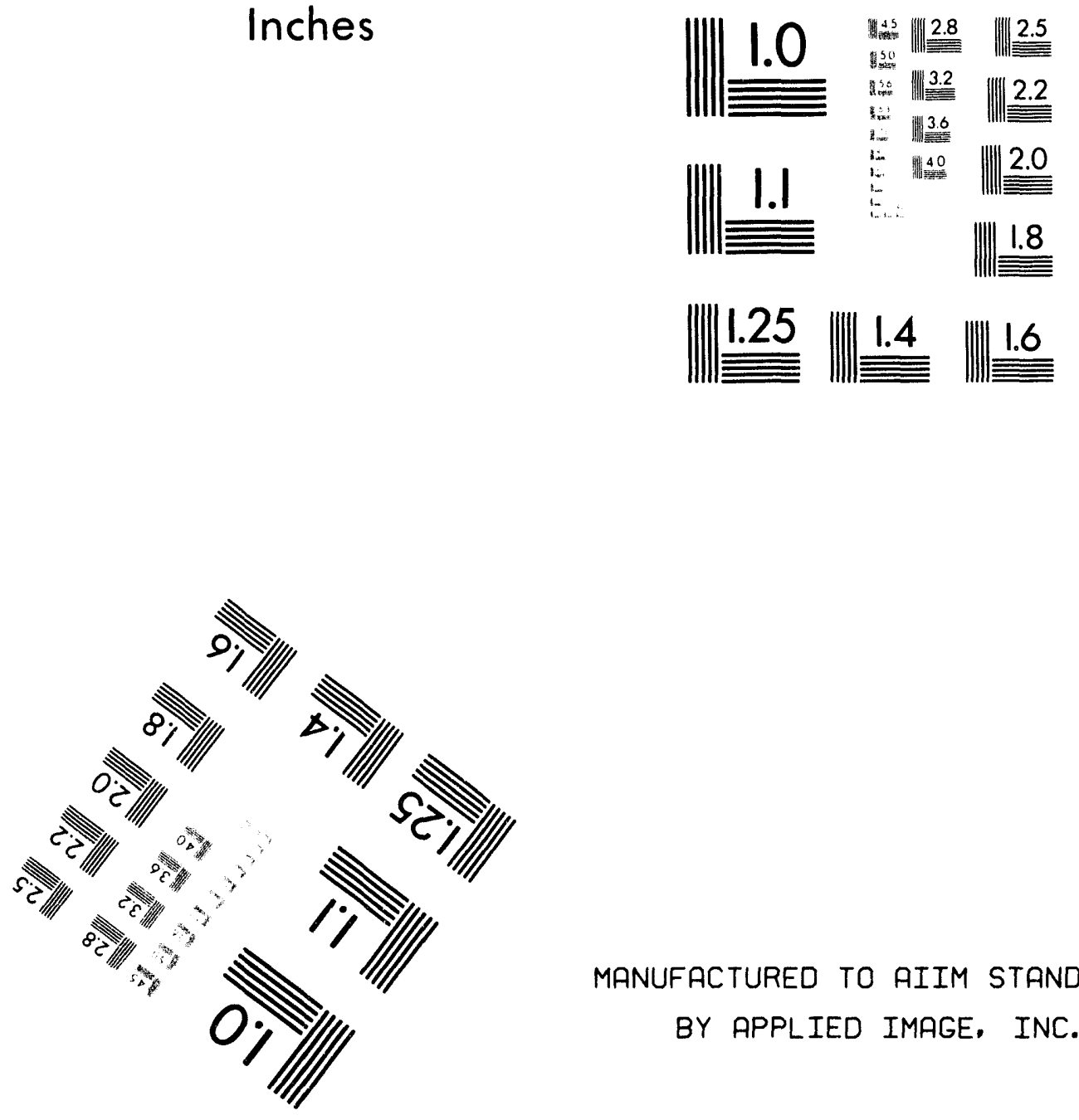

MANUFACTURED TO AIIM STANDARDS BY APPLIED IMAGE, INC.

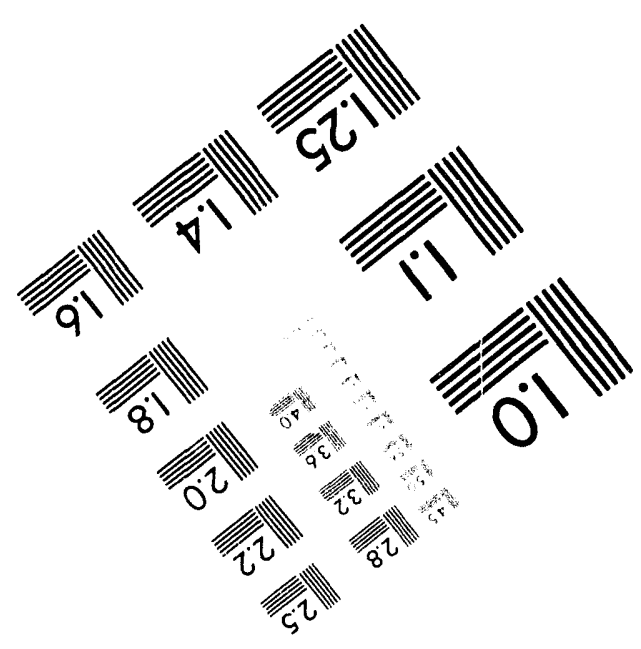


$-$
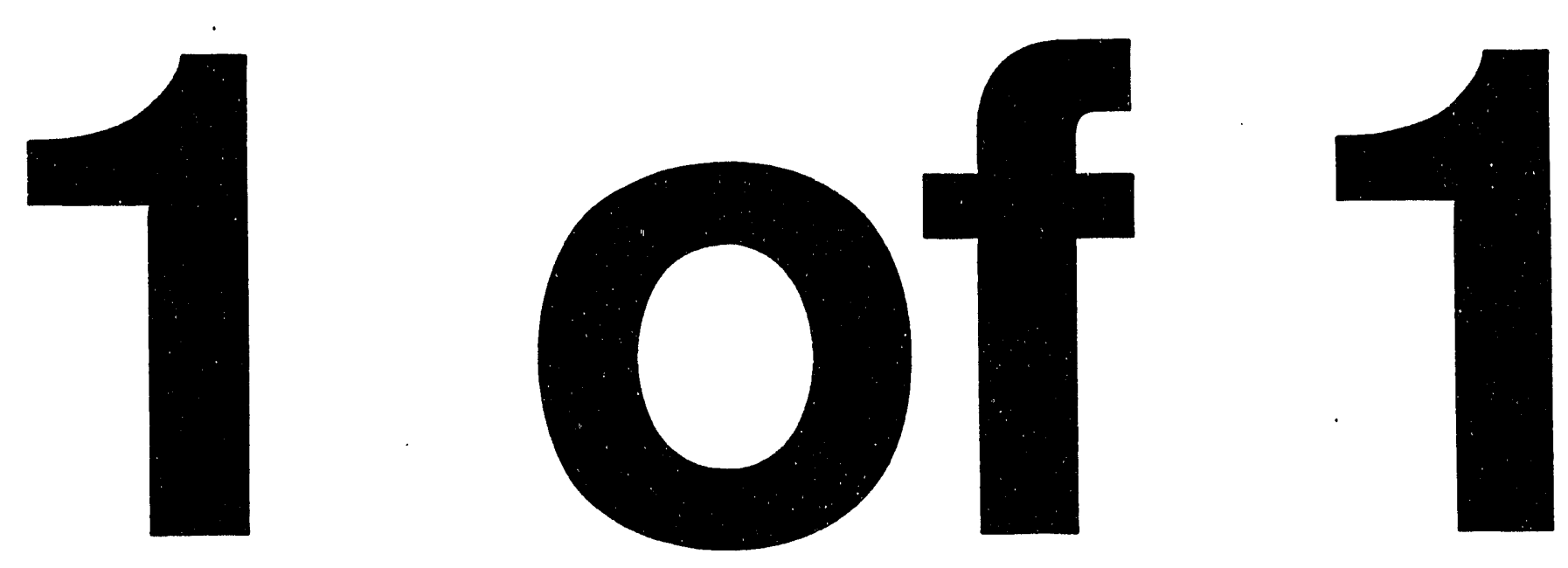
NRTSC

NUCLEAR REACTOR TECHNOLOGY

AND SCIENTIFIC COMPUTATIONS

WSRC-TR $-92-534$
Task No.: $\quad 92-104-1$

KEYWORDS:

ONSET OF FLOW INSTABILITY

ONSET OF SIGNIFICANT VOID

DEMAND CURVES

LOSS OF COOLANT ACCIDENT

ANNULUS

RETENTION:

PERMANENT

\section{EXPERIMENTAL ONSET OF FLOW INSTABILITY TESTING BY CREARE, INC. (U)}

b y

D. A. COUTTS

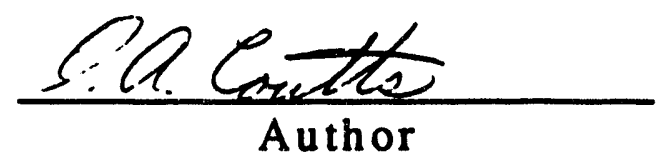

ISSUED: NOVEMBER, 1992

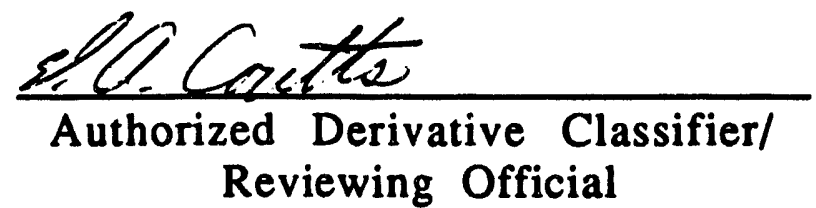

SRL SAVANNAH RIVER TECHNOLOGY CENTER, AIKEN, SC 29808

Westinghouse Savannah River Corporation

Prepared for the U.S. Department of Energy under

Contract DE-AC09-89SR18035 
Document: WSRC-TR-92-534

Title:

EXPERIMENTAL ONSET OF FLOW

INSTABILITY TESTING BY CREARE, INC. (U)

Task:

$92-104-1$

Task title: CREARE OFI TEST PROGRAM

Approvals

$\frac{\text { Charler } a, \text { Nenh }}{\text { C. A. Nash, Technical Reviewer }} \stackrel{5 / 25 / 93}{\text { Date: }}$

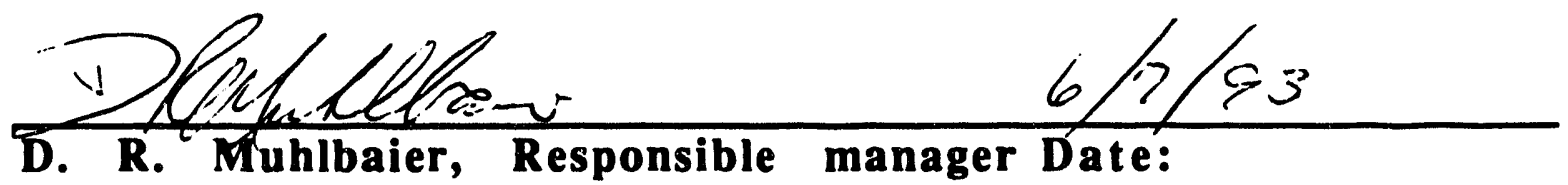

$\frac{\text { Aj Kanett }}{\text { A. J. Garrett, Level } 3 \text { manager }}$




\section{Contents}

Book 1, Final Report

$\begin{array}{lll}\text { 1.0 } & \text { Summary } \\ 2.0 & \text { Introduction } \\ 3.0 & \text { Presentation } \\ 4.0 & \text { Analysis } \\ 5.0 & \text { Results } \\ 6.0 & \text { Discussion } & 1 \\ 7.0 & \text { Conclusions } & \\ 7 & \\ 8.0 & \text { Recommendations } & 5 \\ 9.0 & \text { Nomenclature } & 7 \\ 10.0 & \text { References }\end{array}$

Book 2, Volume 1 of Creare Final Report TN-499

Book 3, Volume 2 of Creare Final Report TN-499

Book 4, Volume 3 of Creare Final Report TN-499

Book 5, Listing of backup documentation provided SRS by Creare

Book 6, Tabular data from data disk 1, 2 and 3

Book 7, Tabular data from data disk 4, 5, and 6

Book 8, Tabular data from data disk 7,8 , and 9

\section{Tables}

Table 1 Instrumentation Used for Construction 1 and 2

Table 2 Test and Construction Matrix

Table 3

Table 4

Table 5 Comparison of Data Presented in Book 2 \& the Reduced Data in Book 3

Table A1

Table A2

Table A3

Table B1

Table B2

Tolerance Intervals for Velocity and Stanton Number at OFI for the Test Runs in

Table 4

Selected Data from Test Feb01_09

Fluid Property Values.

Uncertainty Values for Velocity Prediction for Test Feb01_09

Selected Data from Test Aug01 08

Table B3

Fluid Property Values 


\section{Appendices}

Appendix A, Independent Review Calculations for Test Feb01_09

Appendix B, Independent Review Calculations for Test Aug01_08

Appendix C. Directory of Electronic Data Files by Disk Number

Appendix D, Comparison of Printed and Electronic Data Files

Figures

1 Demand Curve 13

2 Effect of Helium Saturation Pressure on the Demand Curve Minimum

3 Effect of Helium Saturation Pressure on the Stanton Number at the Demand Curve Minimum 


\section{SUMMARY}

Flow excursions can occur during subcooled heated flow if the supply system is not adequate to meet the heated channel pressure demand. Available experimental flow instability (FI) data for ribbed annuli such as usad in the SRS production reactors is very limited. Creare Inc. completed a series of FI tests which included two annular geometries; one of these included metallic ribs which separated the annulus into four sub-channels. This report summarizes the results of the onset of flow instability (OFI) testing which was completed by Creare in support of the SRS Reactor Restart Program. A copy of the final test report has been attached and the archival locations for the supporting documentation and electronic test data is also included.

The purpose of this report is to:

- Archive the Creare Program data;

- Inspect the data which has been archived;

- Review the results presented by Creare;

- Evaluate if the Creare Program data may be used in critical applications.

\section{INTRODUCTION}

Ledinegg [1] identified a mechanism for subcooled flow in heated channels to undergo a sudden large amplitude excursion to a new, stable operating condition. This instability is characterized by a rapid shift in the operating condition from subcooled boiling to high quality steam. The demand curve for heated channels at subcooled conditions is very similar to that of an unheated demand curve as long as the flow velocity is high. As the flow velocity is decreased the similarity between the heated and unheated demand curves will cease. The heated demand curve will pass through a minimum as shown in Figure 1. This minimum is created by an increase in the frictional pressure drop caused by vapor effectively roughening the pipe wall and an increase in the acceleration pressure drop resulting from the generation of vapor. If the supply system is not adequate to meet the demand curve conditions a sudden large amplitude excursion to a new, stable operating condition will occur. This instability is characterized by a rapid shift in the operating condition from subcooled boiling to steam.

Creare, working in conjunction with Stern Laboratories, produced 19 demand curves in two different annuli geometries. The first geometry was a "pure" annulus with the exception of centering pins $\left(0.094^{\prime \prime}\right.$ diameter for first construction and $0.109^{\prime \prime} \times 0.75^{n}$ long for second construction) which were used to hold the inner annulus pipe in position. The second geometry included four ribs which were an integral part of the inner annulus. Heat was generated in both the inner and outer annular walls using resistance element heaters which were electrically isolated from the wetted aluminum.

The results of the test program were transmitted to SRS by Creare in a single report. The report was issued in 3 volumes. In addition nine 3-1/4" micro floppy disks which contained the reduced experimental data and a large collection of backup documentation were also shipped. 


\section{PRESENTATION}

The final Creare report which was issued to SRS with a document number of TN-499 has been reproduced in Books 2, 3, and 4. (This manuscript with appendices is Book 1.) The term books has been used to differentiate it from the term volumes which was used in TN-499. Book 5 contains a listing of all supporting documents which were transmitted by Creare to SRS. These records are filed as Task Number 92-104-1. Books 6,7 , and 8 contain printed versions of the reduced data which was provided by Creare. Table 1 summarizes the document numbers which have been assigned to information which was directly generated as a result of the Creare test program. The reports (books) are available from the SRS records repository. The electronic medium have been stored as part of the Heat Transfer Laboratory (HTL), Building 786-A, electronic records.

The reports in Books 2, 3 and 4 were transmitted from Francis X. Dolan, Project Engineer, Creare, to D. Allan Coutts, SRS on September 15, 1992. The document list in Book 5 was transmitted with the backup documentation in a fire resistant safe. This safe was shipped from Creare to the HTL by motor carrier along with all of the testing equipment which Creare returned to SRS.

\section{ANALYSIS}

Chen and King [2] demonstrated that the calculated condition at OSV (a local phenomena) is a successful precursor to OFI (a global phenomena) using annular data which was generated by Columbia University in 1963. The goal of the Creare test program was to produce demand curves in a test channel with aluminum walls and aluminum ribs which quadiisect the annulus into four subchannels. This data would then be used to further justify the conclusions of Chen and King. Saha and Zuber [3] proposed that for OSV to occur the local Stanton number must exceed 0.0065 . The Stanton number is defined as:

$$
S t=\frac{\phi}{G C_{p}\left(T_{s}-T_{f}\right)}
$$

This value is calculated at local conditions. Each of the quantities in the Stanton number can vary in a segmented annulus. Because of this a different Stanton number is expected for each subchannel at every operating condition. Creare appears to have calculated the Stanton number based on the subchannel averaged conditions. Direct comparison of the Stanton numbers (at the demand curve minimum) computed by Creare with expected Stanton number based on the the modified Saha and Zuber correlation as used by FLOWTRAN are not necessarily appropriate.

The data disks were transmitted from Francis $X$. Dolan, Project Engineer, Creare, to Zafar Qureshi, SRS on November 5, 1990. The disks are DOS compatible. A conversion was necessary to ailow the files to be handled on Macintosh systems. This conversion was completed using Apple File Exchanger, version 6.0.3. The data was extracted from the original disks and written to an internal harddrive on a Macintosh Ilcx with System 7.0 operating system. The data files were then written from the harddrive to a laser optical disk. The tabular data in Book 6 for Disk 1 was printed from 
the files which were on the laser disk. Disks 2 through 9 were printed from the harddrive files. This was necessary because the laser drive unit (the worm) was not continuously available.

Microsoft Word was used to print the data files in Books 6 though 8 . It was necessary to reformat each file prior to printing. The format to allow printing was:

$\begin{array}{ll}\text { Font: } & \text { Courier } \\ \text { Size: } & 10 \\ \text { Top Margin: } & 1^{n} \\ \text { Bottom Margin: } & 0.75^{\prime \prime} \\ \text { Side Margins: } & 1^{n} \\ \text { Borders: } & \text { Plain Box }\end{array}$

The technical review of the information in this report consisted of the checks in Table 2.

\section{RESULTS}

The data in Table 4.1 of Book 2 for two tests (Non-ribbed test series $1 \mathrm{~A}$ and ribbed test series 1A) were compared with the data in Book 3. These comparisons are presented in Table 3. Selected values from Book 3 were also verified. These are listed in Appendices A and B. With the exception of local exit pressure measurements, all variations in the Table 3 data are probably due to roundoff error. The local exit pressures have an unexplained bias. The difference is either 0.2 or 0.3 psi. It is possible that an undiscussed elevation correction has been introduced while converting from the Book 3 reduced data to the data presented in Table 4.1 of Book 2, or that the value was calculated from other measurements. Since the variation is less than the stated uncertainty for the measurements this minor variation should not be considered significant.

The channel pressure drop is presente $J$ in two forms in the Books 3 and 4 . The value is presented in both inches of water and psi. The conversion from inches of water to psi is not provided, however if a water density of $62.42 \# / \mathrm{t}^{3}$ is assumed the two values agree. That this conversion value is not explicitly provided should not impact the quality of the data.

The tabular value SD which is presented in Books 3 and 4 is described as the "standard deviation of the average value calculated from the 50 readings, engineering units." Common standard deviations used in testing include the sample standard deviation [4], S, and standard deviation of the mean [5], $S_{m}$. These terms are calculated as:

$$
S^{2}=\frac{\sum_{i=1}^{N}\left(x_{i}-\bar{x}\right)^{2}}{N-1} \quad S_{m}=\frac{S}{\sqrt{N}}
$$

It is not clear which statistic is meant by the standard deviation of the average value. Since each sample included 50 readings, these two values $\left(S\right.$ and $S_{m}$ ) vary by a factor of about 7. It is assumed (See Appendices A and B for the justification) that the term 
SD is the sample standard deviation'. This assumption may have a significant impact on the uncertainties and safety margins which must be applied when the data in this report is used for design purposes. If the term SD is actually the sample deviation of the mean then the sample confidence interval would be understated by $700 \%$.

It has not been possible to determine how the uncertainties tabulated in Books 3 and 4 were computed. Several variations were attempted (See Appendices A and B), however, none successfully reproduced the stated values. ${ }^{2}$ This discrepancy does not invalidate the use of the Creare data for critical applications as described in the WSRC Manual 1Q. There is nothing in any of the documents that suggests that the data is questionable, rather the requirement in Procedure QAP 3-1 for the test data to be subject to a verified error analysis has not been met. It should be noted that QAP 3-1 requires that the error analysis should become part of the design records. As such, this verification effort is beyond the scope of a data archival report. When the data in this report must be used for critical applications it will be necessary to generate a verified error analysis.

The local measured pressures near the inlet and exit of the channel were compared to the measured pressure drop in Appendices A and B. The calculated pressure drop using the local measurements equaled the measured pressure drops within the stated uncertainties of the instruments.

The uncertainty estimates for the Velocity 1 were checked by independent calculation, using the stated pressure uncertainties of instrument PFM000001. The stated velocity uncertainty for data file Feb01_09 is $14.2 \%$; this is slightly higher than that estimated in Appendix A, 13.8\%. No reason could be identified for this variation, but it is within the accuracy of the calculation. For data file Aug01_08 the stated uncertainty was $16.0 \%$, while the calculated value was $15.9 \%$. This variation was probably due to roundoff. This indicates that the various uncertainties used in the Creare reports should be verifiable if sufficient resources are applied.

Selective magnetic medium data printed in Books 6 though 8 were compared with the magnetic medium data presented in Books 3 and 4 . The selections were made randomly. This comparison only includes one-third of the data files (.SM1 type). The Creare final report did not include two of the three files which were prepared for each test. The three files are: .SM1, .SM2 and .DIF. These files are described in Book 3. The description is repeated below:

"A test is comprised of a period of 300 seconds of steady-state operation of the flow loop and steady annulus boundary conditions, during which time data are automatically recorded by the data acquisition computer. At the conclusion of the test the data are reduced to average values of each measurement for the first 5 seconds of the recording interval and for the last 5 seconds. The differences between these averages are also

Z. H. Qureshi confirmed this assumption with F. X. Dolan in an April 1993 phone conversation. Z. H. Qureshi reports that the percentage of reading uncertainties listed in Table 2.7 of Book 2 must be adjusted to conform to the instrument's actual range. A discrepancy will result if the start of the range is non-zero. The information to complete these calculations should be in the task records. This is based on an April 1993 phone conversation with F. X. Dolan. 
computed. The average values and differences are then written into data summary tables called .SM1 and .SM2 and .DIF files."

The .SM2 and .DIF files in Books 6,7 and 8 have been checked to ensure that the columns correctly contain either numeric or alpha/numeric data as appropriate.

\section{DISCUSSION}

The checks in Table 2 were considered adequate to verify that the test data presented in Books 2, 3, 4, 6, 7 and 8 are appropriate for use in critical applications as discussed in WSRC Manual 1Q, Procedure QAP 2-2. Critical applications as defined by WSRC $1 \mathrm{Q}$ are those where errors may have any of the following consequences:

- pose a significant safety hazard with the potential for serious injury

- risk significant financial loss greater than $\$ 500,000$

- cause a hazardous release of radioactive, or other hazardous material to the environment or cause a hazardous exposure of employees to these materials

- unplanned nuclear criticality

- result in a loss of special nuclear material or the accountability thereof.

The calculations by ANNULUS and the documentation in Appendix A and B of Book 2 have not been reviewed and should not be considered critical data. This critical data conclusion assumes that a logical and defensible design basis which includes applicable safety margins is developed. The development of safety margins and design bases is beyond the scope of this document.

Not all of the data files contained in Books 3 and 4 are available on disk. Data for files Nov13_n1, Jan31_19, and Jul31_23 are available in Book 4 however no electronic records were transmitted to SRS.

Creare presents four conclusions in Book 2.

1. The effect of ribs in the test geometry seems to be the most important with respect of the key result -- the location of OFI.

2. The effect of power tilt requires further study. The experiments show little effect of power tilt, but that appears to be a function of the particular configuration tested.

3. The effect of heat flux, inlet pressure, and asymmetric heating are consistent with expected trends based upon the analytical work.

4. "The effect of dissolved helium does not appear to be significant."

Table 4.1 in Book 2 supports this generalized statement (Conclusion 1); however, the lowest recorded Stanton number $(0.00330)$ at OFI for non-ribbed annulus falls well below the other non-ribbed data and much of the ribbed data. Since no explanation is presently available to account for this variation, the demonstration of a rib effect in annular channels (Conclusion 1) should be considered inconclusive. 
Conclusion 2 is justified. There is no decisive data which demonstrates the effect of power tilt.

The calculated pressure drops presented in Books 3 and 4 match the data well enough to support Conclusion 3.

The figures presented in Book 2 do not support or refute Conclusion 4. When data is plotted for the six tests with similar boundary conditions (See Tables 4 and 5) a helium effect on OFI is not readily observable because of test to test variations. See Figures 2 and 3 that present the effect of helium on velocity and the Stanton number at the demand curve minimum.

These two figures present some distressing information related to the Creare test program. The variation of the velocity and Stanton Number at the demand curve minimum is much higher than expected. The measurement uncertainties for the velocity was stated at approximately $15 \%$ and the measurement uncertainties for the Stanton Number was stated at 10 to $20 \%$. The confidence values to contain the available data (Table 6) are much higher than these measurement uncertainties. While there is some variation in the variables as presented in Table 5 , the results in Table 6 indicate that additional evaluation of the data is appropriate. Because of this unexplained variation, the conclusion on helium saturation pressure effects on the demand curve minimum may require additional review.

Unexpected variations in the test results (Stanton number at OFI) were earlier identified in Reference 8, which recommend repeating tests $1 \mathrm{~A}$ and 15. These tests were not repeated.

\section{CONCLUSIONS}

1. The experimental data in Books $2,3,4,6,7$, and 8 should be considered appropriate for use in critical applications at SRS.

2. The data in this report must be subject to a verified error analysis prior to its use in critical applications.

3. Additional analysis of the present data is warranted to evaluate the unexplained variation in the measured velocity and Stanton number at the demand curve minimum under similar operating conditions.

4. The conclusion (\#4 in Book 2) that helium does not affect the conditions at OFI is justified at the present level of analysis.

5. The Stanton number OFI thresholds calculated from the data in Books 3 \& 4 were calculated at azimuthal values rather than local values. This deviates from the modified OSV criteria used to set SRS production reactor limits. 


\section{RECOMMENDATIONS}

1. Complete a comprehensive data verification and uncertainty analysis :- $r$ all of the Creare data which is to be used in critical applications.

Items which should be included in this review are:

- Has an elevation correction been included in the local exit pressure measurements?

- What is the appropriate conversion between inches of water and psi (i.e., at what water temperature)?

- How was the helium saturation pressure converted from gange to absolute?

- Can the low Stanton number $(0.00330)$ for the non-ribbed annuli be explained?

2. Calculate the local Stanton number at the demand curve minimum for each test to verify the SRS modified OSV criteria.

\section{NOMENCLATURE}

Af flow area

cp local specific heat

$c_{p s}$ specific heat of the fluid calculated at the local saturation temperature

D. hydraulic diameter

G mass flux

$k_{s}$ thermal conductivity of the fluid calculated at the local saturation temperature

$N$ total number of samples

$\Delta \mathrm{P}$ pressure drop

Pe Peclat number

$Q$ flow

S sample standard deviation

SD standard deviation of the average

$S_{m}$ standard deviation of the sample mean

St Stanton number

$T_{f} \quad l o c a l$ bulk fluid temperature

$\mathrm{T}_{\mathrm{s}} \quad$ local saturation temperature

$v$ velocity

$x_{i} \quad$ a single value from a set of data

$\phi$ heat flux

$p \quad$ density of liquid

$\omega$ uncertainty

\section{REFERENCES}

1 Ledinegg, M., "Instability of Flow During Natural and Forced Circulation", Die Worm, 61, 591-898 (1938), Translation by R. B. Lees, Argonne National Laboratory, Chicago, IL.

2 Chen, Kuo-Fu, and J. F. King, FLOWTRAN Benchmarking with Onset of Flow Instability Data from 1963 Columbia University Experiment, DPST-88-666, October 1988. 
3 Saha, P. and N. Zuber, "Point of Net Vapor Generation and Vapor Void Fraction in Subcooled Boiling", Proceedings of the 5th International Heat Transfer Conference,, Tokyo, Japan, September 3-7, 1974, pages 175-179.

4 Figliola, Richard S., and Donald E. Beasley, Theory and Design for Mecanical Measurements, John Wiley \& Sons, New York, 1991.

5 Holman, J. P., Experimental Methods or Engineers, 3rd Ed., McGraw-Hill Book Co., 1978.

6 Hahn, Gerald J., "Statistical Intervals", Harrison M. Wadworth, Statistical Methods for Engineerings and Scientists, McGraw-Hill Publishing Co., New York, 1990, pp 5.1-5.13.

7 FLOWTRAN Manual, DPSTM-140, Rev 0, Version 16.2, 8/21/89.

8 IOM to J. D. Metzgar, from C. A. Nash, Comments on Review of Creare Stanton Number Calculations, NES-ETH-900312, 9/27/90. 


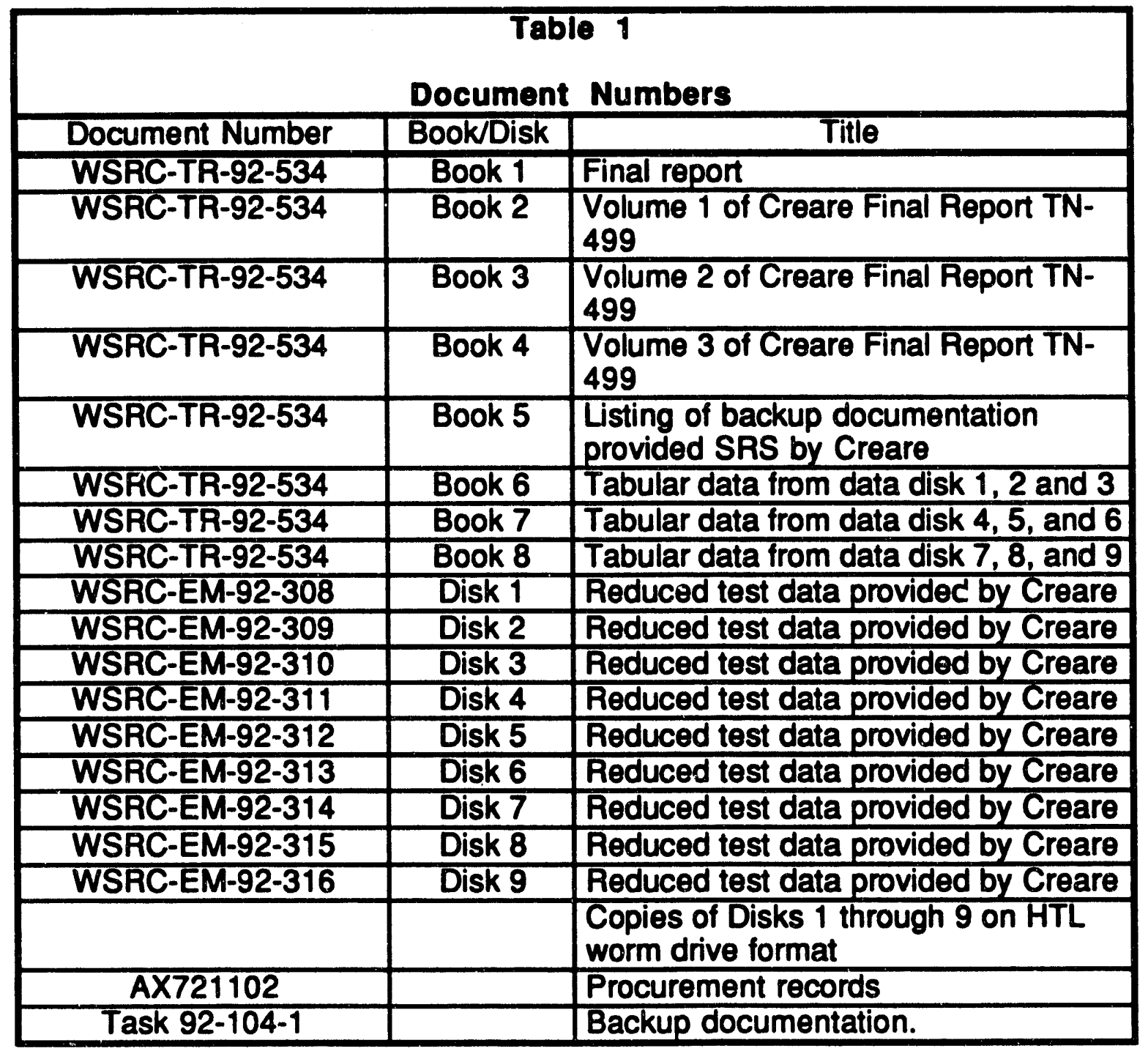




\begin{tabular}{|c|c|c|}
\hline Technical & ow Ch & ocks \\
\hline Check & $\begin{array}{r}\text { Number of } \\
\text { Checks }\end{array}$ & Type of Check \\
\hline $\begin{array}{l}\text { Verify diametral average heat flux } \\
\text { calculation }\end{array}$ & 2 & Independent calculation \\
\hline $\begin{array}{l}\text { Verify outlet average temperature } \\
\text { calculation }\end{array}$ & $\overline{2}$ & Independent calculation \\
\hline $\begin{array}{l}\text { Verity helium saturation pressure } \\
\text { calculation }\end{array}$ & $\overline{2}$ & Independent calculation \\
\hline Verify Stanton number calculation & 2 & Independent calculation \\
\hline Verify Peclet number calculation & $\overline{2}$ & Independent calculation \\
\hline Verify tabulated uncertainty values & 2 & Independent calculation \\
\hline $\begin{array}{l}\text { Complete a pressure summation } \\
\text { check }\end{array}$ & $\overline{2}$ & Calculation \\
\hline Verify the velocity calculation & 2 & Independent calculation \\
\hline $\begin{array}{l}\text { Verify electronic media files (.SM1 } \\
\text { type) }\end{array}$ & 1 per file & Match data in random locations \\
\hline $\begin{array}{l}\text { Verity electronic media files (.SM2 } \\
\text { and .DIF type) }\end{array}$ & each file & $\begin{array}{l}\text { Verity columns have numeric or } \\
\text { alpha/numeric data as } \\
\text { applicable }\end{array}$ \\
\hline $\begin{array}{l}\text { Evaluate if conclusions are supported } \\
\text { by data }\end{array}$ & all & Independent evaluation \\
\hline Evaluate general technical content & all & $\begin{array}{l}\text { Read documents for } \\
\text { understanding }\end{array}$ \\
\hline
\end{tabular}




\section{Table 3}

\section{Comparison of Data Presented in Book 2 and the Reduced Data in Book 3}

\begin{tabular}{|c|c|c|c|c|c|c|}
\hline Condition & \multicolumn{3}{|c|}{ Non-ribbed } & \multicolumn{3}{|c|}{ Ribbed } \\
\hline Test series & & $1 \mathrm{~A}$ & & & $\overline{1 A}$ & \\
\hline Test (data file) & & 06010 & & & 40010 & \\
\hline & $\begin{array}{l}\text { Book 2. } \\
\text { Table 4.1 }\end{array}$ & Book 3 & $\begin{array}{l}\text { Error \% } \\
\text { (Comment) }\end{array}$ & $\begin{array}{l}\text { Book 2, } \\
\text { Table 4.1 }\end{array}$ & Book 3 & $\begin{array}{l}\text { Error \% } \\
\text { (Comment) }\end{array}$ \\
\hline $\begin{array}{l}\text { Diametral Average Heat Flux, } \\
\text { kBtumr-tt2 }\end{array}$ & 100.7 & 100.66 & $0.04(1)$ & 100.9 & 100.95 & $0.04(1)$ \\
\hline Heat Flux Distribution & uniform & uniform & - & unitorm & uniform & . \\
\hline Velocity, fos & 3.49 & 3.4857 & $0.12(1)$ & 3.27 & 3.2735 & $0.11(1)$ \\
\hline Inlet Tomperature, $F$ & 87.7 & 87.69 & $0.01(1)$ & 87.2 & 87.17 & $0.03(1)$ \\
\hline Outlet Average Temperature, $F$ & 236.8 & 236.73 & $0.03(1)$ & 244.9 & 244.93 & $0.01(1)$ \\
\hline Inlet Prossure, psia & 40.4 & 40.4387 & $0.10(2)$ & 40.1 & 40.0797 & $0.05(2)$ \\
\hline Exit Prossuro, psia & 45.4 & 45.2085 & $0.42(3)$ & 45.3 & 45.0459 & $0.56(3)$ \\
\hline Helium Saturation Prossure, psia & 19.6 & 19.6 & $0.00(4)$ & 19.6 & 19.6 & $0.00(4)$ \\
\hline Stanton Number & 0.00330 & 0.003328 & $0.85(1)$ & 0.00451 & 0.004556 & $1.02(1)$ \\
\hline Pecler Number & 88500 & 88120 & $0.43(1)$ & 73800 & 73340 & 0.62311 \\
\hline
\end{tabular}

\section{Comments}

1. Error is considered the result of roundoff.

2. During preparation of Book 1, the inlet pressure was assumed to be based on instrument PAB000136. After subsequent review, the use of the data from instrument PINO00001 was found to provide good results.

3. The reason for the error could not be identifizd and was larger than that expected due to roundoff. The difference may be the result of an elevation correction which was not discussed in Books 2, 3 or 4.

4. The barometric pressure was assumed to be 14.6 psia.

\section{Table 4}

Test Files Used for Hellum Effect Evaluation

\begin{tabular}{|c|c|c|}
\hline Test & Geometry & Build \\
\hline Nov14 13 & Non-ribbed & 1 \\
\hline Feb01 09 & Non-ribbed & 2 \\
\hline Feb06 08 & Non-ribbed & 2 \\
\hline May03_21 & Ribbed & 3 \\
\hline May08_08 & Ribbed & 3 \\
\hline Aug01 08 & Ribbed & 4 \\
\hline Aug16 06 & Ribbed & 4 \\
\hline Aug17 31 & Ribbed & 4 \\
\hline Aug17_37 & Ribbed & 4 \\
\hline
\end{tabular}




\begin{tabular}{|l|c|c|c|}
\hline \multicolumn{4}{|c|}{ Table 5 } \\
Range of Flxed Variables for Hellum Effect Evaluation \\
\hline \multicolumn{1}{|c|}{ Variable } & Mean & Minimum & Maximum \\
\hline $\begin{array}{l}\text { Diametral average heat flux, kBtu/hr- } \\
\mathrm{ft}^{2}\end{array}$ & 100.71 & 99.60 & 101.40 \\
\hline Velocity, tps & 3.30 & 3.02 & 3.49 \\
\hline Inlet Temperature, F & 86.80 & 85.10 & 87.70 \\
\hline Outlet Temperature, F & 243.41 & 236.60 & 256.50 \\
\hline Inlet Pressure, psia & 40.14 & 40.00 & 40.40 \\
\hline Exit Pressure, psia & 45.28 & 44.80 & 45.90 \\
\hline
\end{tabular}

\begin{tabular}{|c|c|c|c|c|c|}
\hline Tolerance Int & als for Velc & $\begin{array}{l}\text { Table } \\
\text { alty and } \mathbf{S} \\
\text { Runs in }\end{array}$ & on Num & FI & the Test \\
\hline Geometry & $\begin{array}{l}\text { Number of } \\
\text { Samples }\end{array}$ & Student's t & Average & $\begin{array}{l}\text { Sample } \\
\text { Standard } \\
\text { Deviation }\end{array}$ & \begin{tabular}{|c|} 
Sample \\
Confidence \\
Interval \\
$(95 \%$ \\
coverage)
\end{tabular} \\
\hline Velocity & & & & & \\
\hline Ribbed & $\overline{6}$ & 3.365 & 3.19 fps & 0.258 fps & $27 \%$ \\
\hline Non-ribbed & $\overline{3}$ & 6.965 & 3.35 tps & 0.101 fps & $21 \%$ \\
\hline Stanton Numbe & & & & & \\
\hline Ribbed & $\overline{6}$ & 3.365 & 0.00616 & 0.00249 & $136 \%$ \\
\hline Non-ribbed & $\overline{3}$ & 6.965 & 0.00388 & 0.00055 & $99 \%$ \\
\hline
\end{tabular}




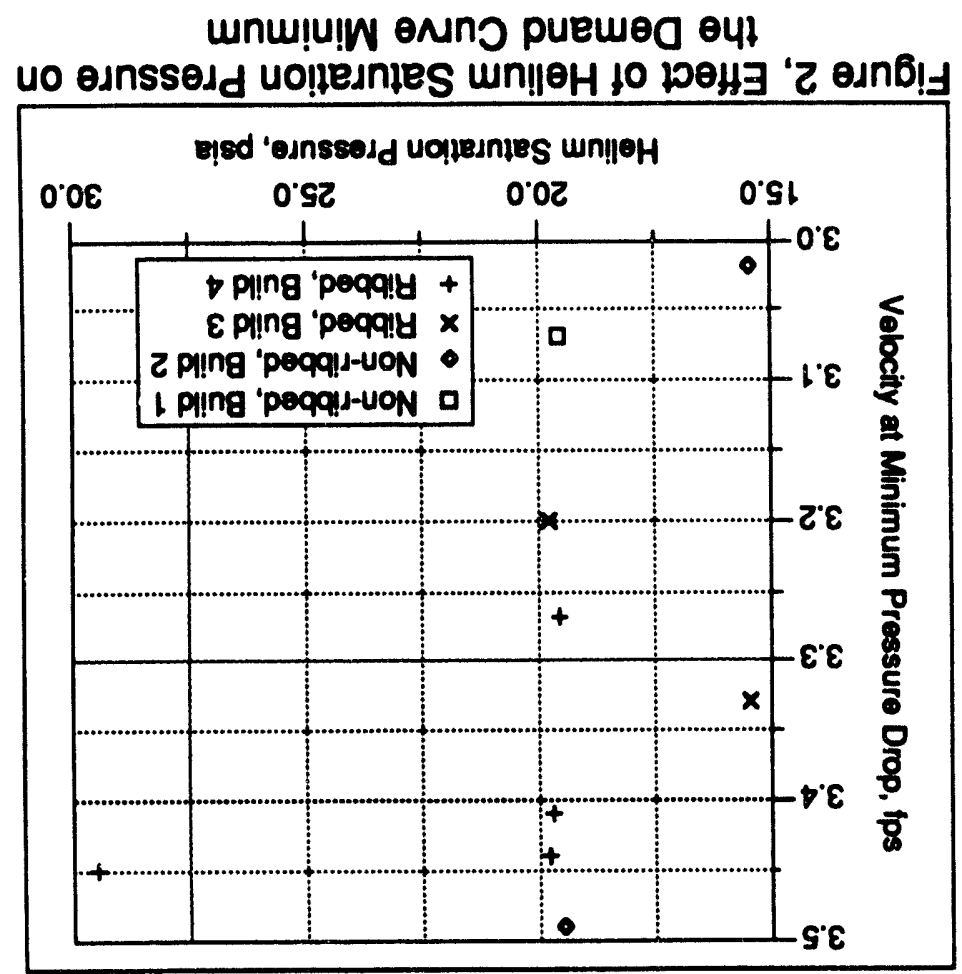

oxn pueweg '

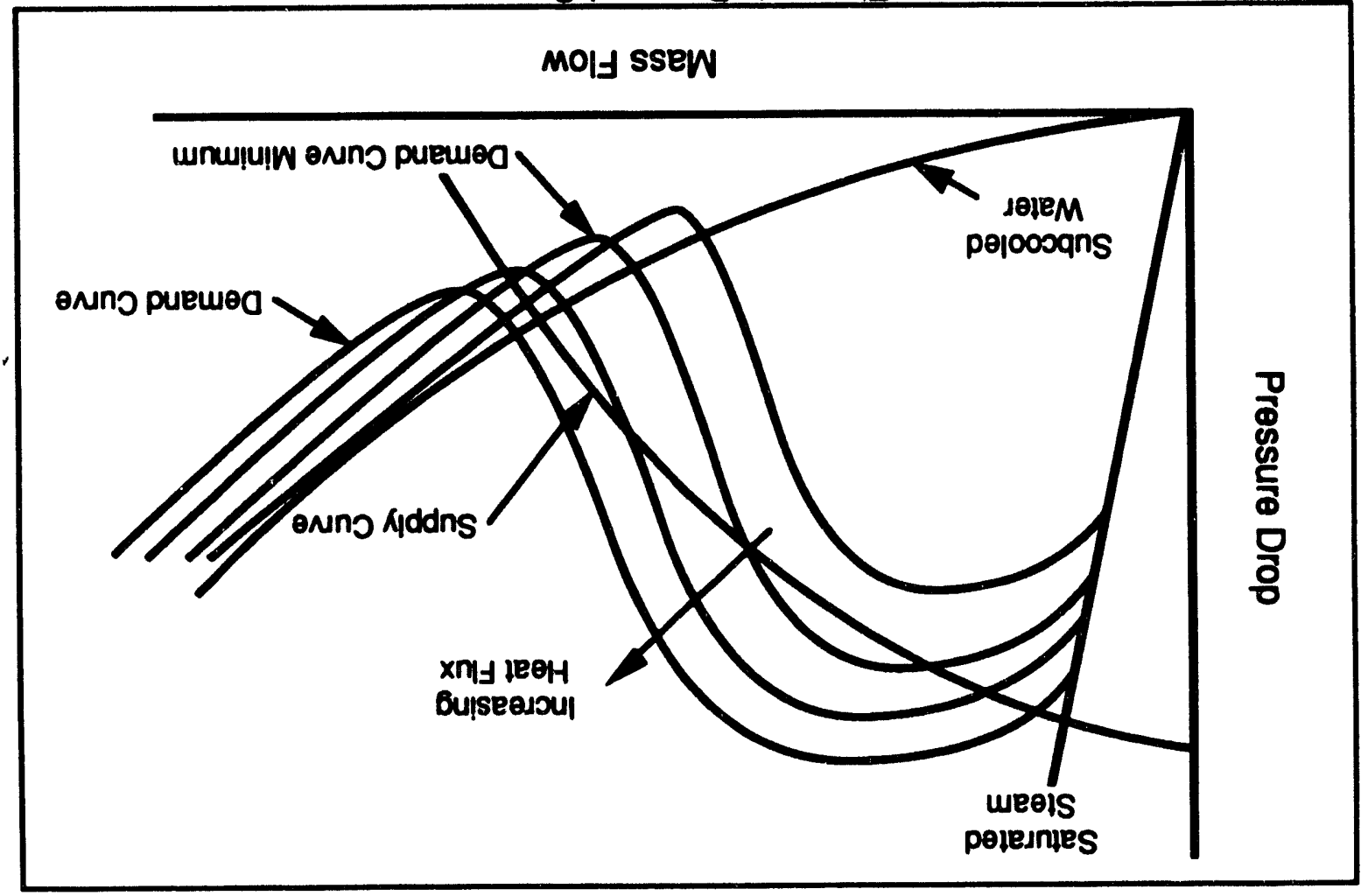




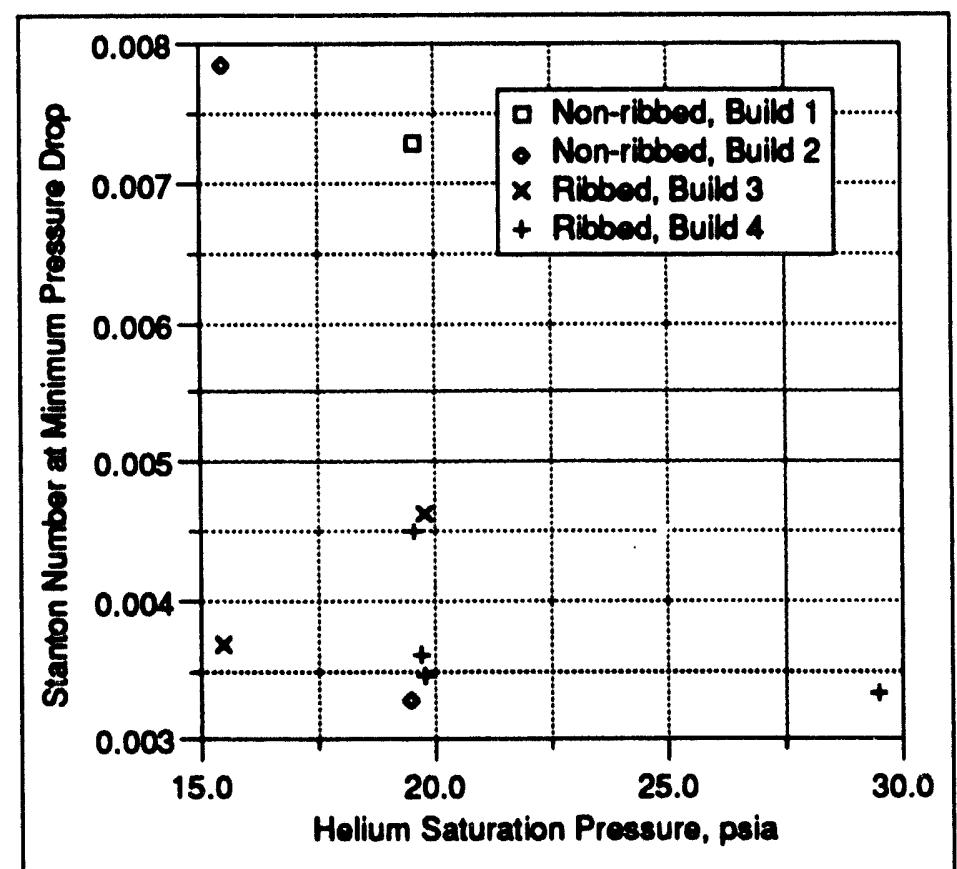

Figure 3, Effect of Helium Saturation Pressure on the Stanton Number at the Demand Curve Minimum 
Appendix A 


\section{Independent Review Calculations for Test Feb01_09}

Summary - Selected data from test Feb01_09 are listed in Table A1. This data has been used for the calculations presented in this Appendix. The parameters presented in Table 3 which could be directly compared without calculations were the heat flux distribution, velocity, inlet temperature, inlet pressure, and outlet pressure.

Diametral Average Heat Flux - A sample diametral heat flux calculation was not provided in the Creare reports, the diametral heat flux used for comparisons was calculated from the data in Table $\mathrm{A} 1$ as shown below:

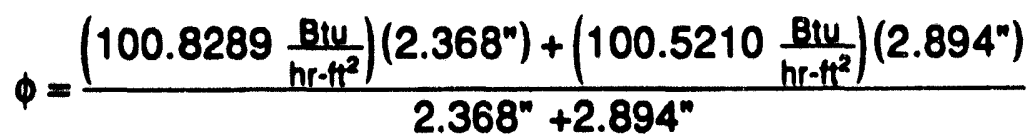

$$
\begin{aligned}
& =100.66 \frac{\mathrm{Btu}}{\mathrm{hr}-\mathrm{Ht}^{2}}
\end{aligned}
$$

Outlet Average Temperature - The outlet temperature was calculated as the arithmetic mean of the temperature measurements TAF130136, TAF130048, TAF130224, and TAF130312. This mean was $236.73 \mathrm{~F}$.

Hellum Saturation Pressure - The method used by Creare to convert the helium saturation pressure reported in Books 3 and 4 in units of psig to units of psia as presented in Book 2 was not presented. If the barometric pressure is assumed as 14.6 psia then there is no problem in completing the conversion.

Stanton Number - Creare defined the Stanton number as:

$$
S t \equiv \frac{\phi}{G C_{p s}\left(T_{s}-T_{f}\right)}
$$

It is important to note that the fluid properties were evaluated at the annulus exit saturation temperature. While Saha and Zuber [3] do not explicitly specify that the fluid properties be taken at the local bulk conditions, it seems implied by their energy balance equation which was used to calculate the equilibrium vapor quality at the point of net vapor generation. The Stanton number will be calculated using both methods.

The mass flux, G, was calculated based on the inlet fluid properties and Velocity 1. The fluid properties used for calculations are tabulated in Table A2.

The Stanton number based on the fluid properties calculated at the saturated temperature is:

$$
\begin{aligned}
S t & =\frac{\left(100.7 \frac{\mathrm{kBtu}}{\mathrm{hr} \cdot \mathrm{th}^{2}}\right)\left(3154 \frac{\mathrm{W} / \mathrm{m}^{2}}{\mathrm{kBtumr} / \mathrm{t}^{2}}\right)}{\left(994.80 \frac{\mathrm{kg}}{\mathrm{m}^{3}}\right)\left(\frac{3.4857 \mathrm{pg}}{3.281 \mathrm{k} / \mathrm{m}}\right)\left(4280 \frac{\mathrm{J}}{\mathrm{kg}-\mathrm{C}}\right)\left(\frac{274.71-236,73 \mathrm{~F}}{1.8 \mathrm{~F} / \mathrm{C}}\right)} \\
& =0.003328
\end{aligned}
$$


The Stanton number based on the fluid properties calculated at the local bulk temperature is:

$$
\begin{aligned}
S t & =\frac{\left(100.7 \frac{\mathrm{kBlu}}{\mathrm{hr}-\mathrm{H}^{2}}\right)\left(3154 \frac{\mathrm{W} / \mathrm{m}^{2}}{\mathrm{kBtumr- \textrm {t } ^ { 2 }}}\right)}{\left(994.80 \frac{\mathrm{kg}}{\mathrm{m}^{3}}\right)\left(\frac{3.4857 \mathrm{ps}}{3.281 \mathrm{H} / \mathrm{m}}\right)\left(4237 \frac{\mathrm{J}}{\mathrm{kg}-\mathrm{C}}\right)\left(\frac{274.71-236.73 \mathrm{~F}}{1.8 \mathrm{~F} / \mathrm{C}}\right)} \\
& =0.003361
\end{aligned}
$$

The specific heat used by FLOWTRAN (7) is assumed constant ( $4186.8164 \mathrm{~J} / \mathrm{kg}-\mathrm{C})$. The FLOWTRAN calculated Stanton number would be 0.003436 .

The variation from the local property Stanton number value would be:

$$
\begin{array}{lr}
\text { Saturated properties } & -1.0 \% \\
\text { Local bulk properties } & 0.0 \% \\
\text { FLOWTRAN } & +2.2 \%
\end{array}
$$

Peclet Number - Creare defined the Peclet number as:

$$
P_{\theta}=\frac{G C_{p s} D_{0}}{k_{8}}
$$

As with the Stanton number, the fluid properties were evaluated at the annulus exit saturation temperature. The hydraulic radius used in the calculation was $0.044 \mathrm{ft}$ as given by Equation 2 in Book 2 rather than the $0.0438 \mathrm{ft}$ tabulated in Book 3 . The Peclet number based on the fluid properties calculated at the saturated temperature is:

$$
\begin{aligned}
P_{0} & =\frac{\left(994.80 \frac{\mathrm{kg}}{\mathrm{m}}\right)\left(\frac{3.4857 \mathrm{tp}}{3.281 \mathrm{t} / \mathrm{m}}\right)\left(4280 \frac{\mathrm{J}}{\mathrm{kg}-\mathrm{C}}\right)\left(\frac{0.04 \mathrm{th}}{3.281 \mathrm{t} / \mathrm{m}}\right)}{0.68842 \frac{\mathrm{W}}{\mathrm{m} C}} \\
& =88120
\end{aligned}
$$

The Peclet number based on the fluid properties calculated at the local bulk temperature is:

$$
\begin{aligned}
P_{\theta} & =\frac{\left(994.80 \frac{\mathrm{kg}}{\mathrm{m}^{3}}\right)\left(\frac{3.4857 \mathrm{fg}}{3.281 \mathrm{t} / \mathrm{m}}\right)\left(4237 \frac{\mathrm{d}}{\mathrm{kg}-\mathrm{C}}\right)\left(\frac{0.04 \mathrm{th}}{3.281 \mathrm{tVm}}\right)}{0.68550 \frac{\mathrm{W}}{\mathrm{m} C}} \\
& =87600
\end{aligned}
$$

These two values differ by 0.6 percent.

Channel Pressure Drop - The channel pressure drop is presented in two forms: inches of water and psi. The conversion from inches of water to psi is not provided, however if a water density of $62.42 \mathrm{w}^{\mathrm{t}} \mathrm{t}^{3}$ is assumed the two values agree. The tabular value, SD is described as the "standard deviation of the average value calculated from the 50 readings, engineering units." Common standard deviations used in testing 
include the sample standard deviation [4], S, and standard deviation of the mean [5], $S_{m}$.

$$
S^{2}=\frac{\sum_{i=1}^{N}\left(x_{i}-\bar{x}\right)^{2}}{N-1} \quad S_{m}=\frac{S}{\sqrt{N}}
$$

It is not clear which statistic is meant by the standard deviation of the average value, SD. The data provided for instrument PANO00136 is:

$\begin{array}{lr}\text { Maximum value } & -135.5771 \mathrm{NH}_{2} \mathrm{O} \\ \text { Minimum value } & -131.9150 \mathrm{NH}_{2} \mathrm{O} \\ \text { Average } & -133.9750 \mathrm{NH}_{2} \mathrm{O} \\ \text { SD } & 0.8233 \mathrm{NH}_{2} \mathrm{O} \\ \text { Uncertainty } & 4.9314 \mathrm{NH}_{2} \mathrm{O}\end{array}$

If the value of SD is considered a standard deviation of the mean then the sample standard deviation for the 50 samples would be $5.82 " \mathrm{H}_{2} \mathrm{O}$. Since the difference between the mean and the two extremes is 1.6021 and 2.0600 , it is unlikely that the sample confidence interval (twice the sample standard deviation) [6] would be $11.64^{\mathrm{N}} \mathrm{H}_{2} \mathrm{O}$.

The value of SD has therefore been assumed to represent the sample standard deviation. The confidence interval to contain the mean (twice the standard deviation of the mean) would then be $0.2329 \mathrm{H}_{2} \mathrm{O}$.

It has not been possible to determine how the uncertainty was computed by Creare. This evaluation has been completed for several instruments, the results were similar for most. The uncertainties for instrument PANO00136 have been separated into a fixed $\left(4.9^{\mathrm{n}} \mathrm{H}_{2} \mathrm{O}\right)$ and a variable term $(0.25 \%$ of reading). These values are stated at the $95 \%$ confidence level (i.e. 2o). Combining these two values using the Root-SumSquare method:

$$
\begin{gathered}
\omega=\sqrt{\left(4.9^{n}\right)^{2}+\left[\left(133.9750^{n}\right)\left(\frac{0.25 \%}{100 \%}\right)\right]^{2}} \\
=4.9114^{n} \mathrm{H}_{2} \mathrm{O}
\end{gathered}
$$

If the uncertainty calculated as the sample standard deviation is also included:

$$
\begin{gathered}
\omega=\sqrt{\left(4.9^{n}\right)^{2}+\left[(133.9750 \mu)\left(\frac{0.25 \%}{100 \%}\right)\right]^{2}+\left[2.0\left(0.82330^{n}\right)\right]^{2}} \\
=5.1801^{n} \mathrm{H}_{2} \mathrm{O}
\end{gathered}
$$

If the variable uncertainties are treated as confidence intervals:

$$
\omega=\sqrt{\left(4.9^{n}\right)^{2}+\left[\frac{\left(133.9750^{n}\right)\left(\frac{0.25 \%}{100 \%}\right)}{\sqrt{50}}\right]^{2}+\left[2.0\left(\frac{0.82330^{n}}{\sqrt{50}}\right)\right]^{2}}
$$


If only the sample standard deviation is treated as a confidence interval:

$$
\begin{gathered}
\omega=\sqrt{\left(4.9^{n}\right)^{2}+\left[\left(133.9750^{n}\right)\left(\frac{0.25 \%}{100 \%}\right)\right]^{2}+\left[2.0\left(\frac{0.82330^{n}}{\sqrt{50}}\right)\right]^{2}} \\
=4.9170^{n} \mathrm{H}_{2} \mathrm{O}
\end{gathered}
$$

None of the above values equal the tabulated value provided by Creare. ${ }^{3}$

Pressure Summation - The pressure taps for the differential pressure instrument PAN000136 were at $1.75^{\prime \prime}$ and $152.75^{\circ}$ from the start of the heated length in the $136^{\circ}$ circumferential location. The taps for local pressure instruments PAB000136 and PAB125136 were at 1.75 and $146.75^{\prime \prime}$ from the start of the heated length. The differential pressure instrument PAN130136 spanned the taps between 146.75 and $152.75^{\prime \prime}$ in the $136^{\circ}$ circumferential location.

The pressure difference between the inlet and the outlet coupled with the pressure drop measured by PAN130136 should equal the overall measured pressure drop.

$$
\begin{aligned}
\Delta P & =40.6122 \mathrm{psi}-45.2085 \mathrm{psi}-\left(4.5284^{\prime \prime} \mathrm{H}_{2} \mathrm{C}\right)\left(\frac{0.03612 \mathrm{psi}}{{ }^{\mathrm{H}} \mathrm{H}_{2} \mathrm{O}}\right) \\
& =-4.7599 \mathrm{psi} \\
\omega & =\sqrt{(0.58882 \mathrm{psi})^{2}+(0.59091 \mathrm{psi})^{2}+\left[\left(0.87007^{\prime \prime} \mathrm{H}_{2} \mathrm{O}\right)\left(\frac{0.03612 \mathrm{psi}}{{ }^{\mathrm{N}} \mathrm{H}_{2} \mathrm{O}}\right)^{2}\right.} \\
& =0.8348 \mathrm{psi}
\end{aligned}
$$

The measured pressure drop (PANO00136) is $-4.8380 \pm 0.1781$ psi and is equal to the calculated value (within the stated uncertainties).

Velocity - A sample calculation for the velocity was not provided. The channel flow rate was apparently measured using flow nozzles and pressure transducers. The averaged tabular data from instrument PFM000001 is listed in inches of water. While it is not possible to reproduce the actual calculation of the velocity it is possible to reproduce the uncertainty calculation. The velocity solution is assumed in the form:

$$
v=\frac{Q}{A_{f}}=K \frac{\sqrt{\Delta P}}{A_{1}}
$$

The value of $K$ can be estimated from the Feb01_09 test data.

2. H. Qureshi reports that the percentage of reading uncertainties listed in Table 2.7 of Book 2 must be adjusted to conform to the instrument's actual range. A discrepancy will result it the start of the range is non-zero. The information to complete these calculations should be in the task records. This is based on an April 1993 phone conversation with F. X. Dolan. 


$$
\begin{aligned}
K & =\frac{(3.4857 \mathrm{fps})\left(0.0151 \mathrm{ft}^{2}\right)}{\sqrt{1.83135^{\mathrm{n}} \mathrm{H}_{2} \mathrm{O}}} \\
& =0.03908 \frac{\mathrm{t}^{3}}{\mathrm{~s} \sqrt{\mathrm{H} 2 \mathrm{O}}}
\end{aligned}
$$

The partial derivatives of the velocity equation are:

$$
\frac{\partial v}{\partial \Delta P}=\frac{-K}{2 A_{f} \sqrt{\Delta P}} \quad \frac{\partial v}{\partial A_{f}}=\frac{-K \sqrt{\Delta P}}{A_{f}^{2}}
$$

The uncertainty terms are summarized in Table A3. It has been assumed that any uncertainty in the value of $K$ has been eliminated by a loop calibration process. If the uncertainties are combined using the Root-Sum-Square method then:

$$
\begin{aligned}
\omega & =\left[\left\{\left[\frac{0.03908}{2(0.0151) \sqrt{1.8135}}\right][0.500]\right\}^{2}+\left\{\left[\frac{(0.03908) \sqrt{1.8135}}{(0.0151)}\right][0.0005]\right\}^{2}\right]^{1 / 2} \\
& =[0.2308+0.0000]^{1 / 2} \\
& =0.480 \mathrm{ps} \text { or } 13.78 \%
\end{aligned}
$$

This is close to the stated value of 14.2158 percent.

\begin{tabular}{|l|c|c|c|}
\hline \multicolumn{4}{|c|}{ Table A1 } \\
\hline \multicolumn{4}{|c|}{ Paramelected data from Test Feb01 09 } \\
\hline & Value & $\begin{array}{c}\text { Standard } \\
\text { Deviation }\end{array}$ & $\begin{array}{c}\text { Measure- } \\
\text { ment } \\
\text { Uncertainty }\end{array}$ \\
\hline Velocity 1, fps & 3.4857 & - & $\pm 14.2158 \%$ \\
\hline Pressure drop, psi & -4.8392 & - & - \\
\hline Saturation temperature at exit, F & 274.7266 & - & - \\
\hline Inner heat flux, kBtu/hr-ft2 & 100.8289 & - & $\pm 1.5659 \%$ \\
\hline Outer heat flux, kBtu/hr-ft2 & 100.5210 & - & $\pm 1.5532 \%$ \\
\hline Hydraulic diameter, feet & 0.0438 & - & - \\
\hline TIN00001, inlet fluid temperature, F & 87.6897 & 0.15142 & \pm 1.9002 \\
\hline TAF130136, outlet fluid temperature, F & 231.6755 & 0.46540 & \pm 1.9175 \\
\hline TAF130048, outlet fluid temperature, F & 244.3002 & 0.48828 & \pm 1.9204 \\
\hline TAF130224, outlet fluid temperature, F & 226.3659 & 0.511117 & \pm 1.9164 \\
\hline TAF130312, outlet fluid temperature, F & 244.5651 & 0.49166 & \pm 1.9204 \\
\hline PAB000316, inlet pressure, psia & 40.6122 & 0.74124 & \pm 0.58882 \\
\hline PIN000001, inlet pressure, psia & 40.4387 & 0.13317 & \pm 0.75678 \\
\hline PAB125136, outlet pressure, psia & 45.2085 & 0.049709 & \pm 0.59091 \\
\hline PAN000136, pressure drop, "H, & -133.9750 & 0.82330 & \pm 4.9314 \\
\hline PAN130136, pressure drop, "H, ${ }_{2} \mathrm{O}$ & -4.5284 & 0.32423 & \pm 0.87007 \\
\hline PFM000001, flow, "H, & 1.8135 & 0.076263 & \pm 0.50002 \\
\hline He saturation pressure, psig & 5 & - & - \\
\hline
\end{tabular}




\begin{tabular}{|c|c|c|c|}
\hline \multicolumn{4}{|c|}{ Table A2 } \\
\hline $\begin{array}{c}\text { Femperature, C } \\
\text { (F) }\end{array}$ & $\begin{array}{c}\text { Density [7] } \\
\mathrm{kg} / \mathrm{m}^{3}\end{array}$ & $\begin{array}{c}\text { Specific Heat [4] } \\
\text { J/kg-C }\end{array}$ & $\begin{array}{c}\text { Thermal } \\
\text { Conductivity [7] } \\
\text { W/m-C }\end{array}$ \\
\hline $30.94(87.69)$ & 994.80 & 4182 & 0.61912 \\
\hline $113.74(236.73)$ & 948.39 & 4237 & 0.68550 \\
\hline $134.85(274.73)$ & 931.53 & 4280 & 0.68842 \\
\hline
\end{tabular}

\begin{tabular}{|c|c|c|c|c|}
\hline \multicolumn{5}{|c|}{ Table A3 } \\
\multicolumn{7}{|c|}{ Uncertainty Values for Velocity Predictlon for Test Feb01 09 } \\
\hline Parameter & Value & Bias & Precision & Combined \\
\hline Area & $0.0151 \mathrm{ft}^{2}$ & $\pm 0.0005 \mathrm{ft}^{2}$ & 0 & $0.0005 \mathrm{ft}^{2}$ \\
\hline Pressure drop & $1.8135 \mathrm{H}_{2} \mathrm{O}$ & $0.5 \mathrm{H}_{2} \mathrm{O}$ & $0.25 \%$ reading & $0.50002 \mathrm{H}_{2} \mathrm{O}$ \\
\hline
\end{tabular}


Appendix B 


\section{Independent Review Calculations for Test Aug01_08}

Summary - Selected data from test Aug01_08 are listed in Table B1. This data has been used for the calculations presented in this Appendix. The parameters presented in Table 3 which could be directly compared without calculations were the heat flux distribution, velocity, inlet temperature, inlet pressure, and outlet pressure.

Dlametral Average Heat Flux - A sample diametral heat flux calculation was not provided in the Creare reports, the diametral heat flux used for comparisons was calculated from the data in Table B1 as shown below:

$$
\begin{aligned}
\phi & =\frac{\left(101.0104 \frac{B t u}{h r-t^{2}}\right)\left(2.353^{n}\right)+\left(100.9008 \frac{B t u}{h r-\Delta t^{2}}\right)\left(2.896^{n}\right)}{2.353^{n}+2.896^{n}} \\
& =100.95 \frac{B t u}{h r-t t^{2}}
\end{aligned}
$$

Outlet Average Temperature - The outlet temperature was calculated as the arithmetic mean of the temperature measurements TAF130136, TAF130048, TAF130224, and TAF130312. This mean was $244.93 \mathrm{~F}$.

Helium Saturation Pressure - The method used to by Creare to convert the helium saturation pressure reported in Books 3 and 4 in units of psig to units of psia as presented in Book 2 was not presented. If the barometric pressure is assumed as 14.6 psia then there is no problem in completing the conversion.

Stanton Number - Creare defined the Stanton number as:

$$
S t \equiv \frac{\phi}{G C_{p s}\left(T_{s}-T_{f}\right)}
$$

It is important to note that the fluid properties were evaluated at the annulus exit saturation temperature. While Saha and Zuber [3] do not explicitly specify that the fluid properties be taken at the local bulk conditions, it seems implied by their energy balance equation which was used to calculate the equilibrium vapor quality the the point of net vapor generation. The Stanton number will be calculated using both methods.

The mass flux, G, was calculated based on the inlet fluid properties and Velocity 1. The fluid properties used for calculations are tabulated in Table B2.

The Stanton number based on the fluid properties calculated at the saturated temperature is:

$$
\begin{aligned}
S t & =\frac{\left(100.9 \frac{\mathrm{kBtu}}{\mathrm{hr}-\mathrm{-1} \mathrm{t}^{2}}\right)\left(3154 \frac{\mathrm{W} / \mathrm{m}^{2}}{\mathrm{kBtu} / \mathrm{hr}-\mathrm{tt}^{2}}\right)}{\left(994.91 \frac{\mathrm{kg}}{\mathrm{m}^{3}}\right)\left(\frac{3.2735 \mathrm{tps}}{3.281 \mathrm{tt} / \mathrm{m}}\right)\left(4279 \frac{\mathrm{J}}{\mathrm{kg}-\mathrm{C}}\right)\left(\frac{274.51-244.93 \mathrm{~F})}{1.8 \mathrm{~F} / \mathrm{C}}\right.} \\
& =0.004556
\end{aligned}
$$


The Stanton number based on the fluid properties calculated at the local bulk temperature is:

$$
\begin{aligned}
S t & =\frac{\left(100.9 \frac{\mathrm{kBtu}}{\mathrm{hr}-\mathrm{ft} \mathrm{t}^{2}}\right)\left(3154 \frac{\mathrm{W} / \mathrm{m}^{2}}{\mathrm{kBtu} / \mathrm{hr}-\mathrm{t}^{2}}\right)}{\left(994.91 \frac{\mathrm{kg}}{\mathrm{m}^{3}}\right)\left(\frac{3.2735 \mathrm{fps}}{3.281 \mathrm{tum}}\right)\left(4244 \frac{\mathrm{J}}{\mathrm{kg}-\mathrm{C}}\right)\left(\frac{274.51-244.93 \mathrm{~F}}{1.8 \mathrm{FC}}\right)} \\
& =0.004597
\end{aligned}
$$

The specific heat used by FLOWTRAN [7] is assumed constant ( $4186.8164 \mathrm{~J} / \mathrm{kg}-\mathrm{C})$. The FLOWTRAN calculated Stanton number would be 0.004660 .

The variation from the local property Stanton number value would be:

$$
\begin{array}{lr}
\text { Saturated properties } & -0.9 \% \\
\text { Local bulk properties } & 0.0 \% \\
\text { FLOWTRAN } & +1.4 \%
\end{array}
$$

Peclet Number - Creare defined the Peclet number as:

$$
P_{\theta} \equiv \frac{G c_{p s} D_{0}}{k_{s}}
$$

As with the Stanton number, the fluid properties were evaluated at the annulus exit saturation temperature. The hydraulic radius used in the calculation was $0.044 \mathrm{ft}$ as given by Equation 2 in Book 2 rather than the $0.0438 \mathrm{ft}$ tabulated in Book 3 . The Peclet number based on the fluid properties calculated at the saturated temperature is:

$$
\begin{aligned}
P e & =\frac{\left(994.91 \frac{\mathrm{kg}}{\mathrm{m}^{3}}\right)\left(\frac{3.2735 \mathrm{fps}}{3.281 \mathrm{ttm}}\right)\left(4279 \frac{\mathrm{J}}{\mathrm{kg}-\mathrm{C}}\right)\left(\frac{0.039 \mathrm{t}}{3.281 \mathrm{ttm}}\right)}{0.68842 \frac{\mathrm{W}}{\mathrm{m}-\mathrm{C}}} \\
& =73340
\end{aligned}
$$

The Peclet number based on the fluid properties calculated at the local bulk temperature is:

$$
\begin{aligned}
P \theta & =\frac{\left(994.91 \frac{\mathrm{kg}}{\mathrm{m}^{3}}\right)\left(\frac{3.2735 \mathrm{fps}}{3.281 \mathrm{ftm}}\right)\left(4244 \frac{\mathrm{J}}{\mathrm{kg}-\mathrm{C}}\right)\left(\frac{0.039 \mathrm{H}}{3.281 \mathrm{tt} / \mathrm{m}}\right)}{0.68842 \frac{\mathrm{W}}{\mathrm{m}-\mathrm{C}}} \\
& =72900
\end{aligned}
$$

These two values differ by 0.5 percent.

Channel Pressure Drop - The channel pressure drop is presented in two forms: inches of water and psi. The conversion from inches of water to psi is not provided, however if a water density of $62.42 \# / \mathrm{ft}^{3}$ is assumed the two values agree. The tabular value, SD is described as the "standard deviation of the average value calculated from 
the 50 readings, engineering units." Common standard deviations used in testing include the sample standard deviation [4], S and standard deviation of the mean [5], $S_{m}$.

$$
S^{2}=\frac{\sum_{i=1}^{N}\left(x_{i}-\bar{x}\right)^{?}}{N-1} \quad S_{m}=\frac{S}{\sqrt{N}}
$$

It is not clear which statistic is meant by the standard deviation of the average value, SD. The data provided for instrument PAN000136 is:

$\begin{array}{lr}\text { Maximum value } & -136.8970 \mathrm{nH}^{\mathrm{O}} \\ \text { Minimum value } & -131.4039 \mathrm{n}_{2} \mathrm{O} \\ \text { Average } & -133.6011 \mathrm{n}^{\mathrm{H}} \mathrm{O} \\ \mathrm{SD} & 1.1662 \mathrm{n}_{2} \mathrm{O} \\ \text { Uncertainty } & 4.9313 \mathrm{n}_{2} \mathrm{O}\end{array}$

If the value of SD is considered a standard deviation of the mean then the sample standard deviation for the 50 samples would be $8.25^{\prime \prime} \mathrm{H}_{2} \mathrm{O}$. Since the difference between the mean and the two extremes is 3.2959 and 2.1972 , it is unlikely that the sample confidence interval (twice the sample standard deviation) [6] would be $16.49^{n} \mathrm{H}_{2} \mathrm{O}$.

The value of SD has therefore been assumed to represent the sample standard deviation. The confidence interval to contain the mean (twice the standard deviation of the mean) would then be $0.3299^{\prime \prime} \mathrm{H}_{2} \mathrm{O}$.

Pressure Summation - The pressure taps for the differential pressure instrument PAN000136 were at $1.75^{n}$ and $152.75^{\circ}$ from the start of the heated length in the $136^{\circ}$ circumferential location. The taps for local pressure instruments PAB000136 and PAB125136 were at 1.75 and $146.75^{\mathrm{m}}$ from the stant of the heated length. The differential pressure instrument PAN130136 spanned the pas between 146.75 and $152.75^{\prime \prime}$ in the $136^{\circ}$ circumferential location.

The pressure difference between the inlet and the outlet coupled with the pressure drop measured by PAN130136 should equal the overall measured pressure drop.

$$
\begin{aligned}
\Delta P & =40.3552 \mathrm{psi}-45.0459 \mathrm{psi}-\left(1.9651{ }^{n} \mathrm{H}_{2} \mathrm{O}\right)\left(\frac{0.03612 \mathrm{psi}}{{ }^{\mathrm{n}} \mathrm{H}_{2} \mathrm{O}}\right) \\
& =-4.7617 \mathrm{psi} \\
\omega & =\sqrt{(0.58871 \mathrm{psi})^{2}+(0.59083 \mathrm{psi})^{2}+\left[\left(0.87001{ }^{\mathrm{NH}} \mathrm{H}_{2} \mathrm{O}\right)\left(\frac{0.03612 \mathrm{psi}}{{ }^{\mathrm{H}} \mathrm{H}_{2} \mathrm{O}}\right)\right]^{2}} \\
& =0.8347 \mathrm{psi}
\end{aligned}
$$

The measured pressure drop (PANO00136) is $-4.8257 \pm 0.1781$ psi and is equal to the calculated value (within the stated uncertainties).

Velocity - A sample calculation for the velocity was not provided. The channel flow rate was apparently measured using flow nozzles and pressure transducers. The 
averaged tabular data from instrument PFM000001 is listed in inches of water. While it is not possible to reproduce the actual calculation of the velocity it is possible to reproduce the uncertainty calculation. The velocity solution is assumed in the form:

$$
V=\frac{Q}{A_{f}}=K \frac{\sqrt{\Delta P}}{A_{f}}
$$

The value of $K$ can be estimated from the Aug01_08 test data.

$$
\begin{aligned}
K & =\frac{(3.2735 \mathrm{fps})\left(0.0150 \mathrm{t}^{2}\right)}{\sqrt{1.5723^{2} \mathrm{H}_{2} \mathrm{O}}} \\
& =0.03916 \frac{\mathrm{t}^{3}}{\mathrm{~s} \sqrt{\mathrm{H}_{2} \mathrm{O}}}
\end{aligned}
$$

this is within $0.2 \%$ of the value calculated in Appendix A. The partial derivatives of the velocity equation are:

$$
\frac{\partial v}{\partial \Delta P}=\frac{-K}{2 A_{f} \sqrt{\Delta P}} \quad \frac{\partial v}{\partial A_{f}}=\frac{-K \sqrt{\Delta P}}{A_{f}{ }^{2}}
$$

The uncertainty terms are summarized in Table B3. It has been assumed that any uncertainty in the value of $K$ has been eliminated by a loop calibration process. If the uncertainties are combined using the Root-Sum-Square method then:

$$
\begin{aligned}
\omega & =\left[\left\{\left[\frac{0.03916}{2(0.0150) \sqrt{1.5723}}\right][0.500]\right\}^{2}+\left\{\left[\frac{(0.03916) \sqrt{1.5723}}{(0.0150)}\right][0.0002]\right]^{2}\right]^{1 / 2} \\
& =[0.2709+0.0000]^{1 / 2} \\
& =0.520 \text { ps or } 15.90 \%
\end{aligned}
$$

This compares very favorably with the stated value of 15.9876 percent. 


\begin{tabular}{|c|c|c|c|}
\hline $\begin{array}{l}\text { Tat } \\
\text { Solected data ff }\end{array}$ & Test A & & \\
\hline Parameter & Value & $\begin{array}{l}\text { Standard } \\
\text { Deviation }\end{array}$ & $\begin{array}{c}\text { Measure- } \\
\text { ment } \\
\text { Uncertainty }\end{array}$ \\
\hline Velocity 1, fps & 3.2735 & - & $\pm 15.9876 \%$ \\
\hline Pressure droo, psi & -4.8257 & $=$ & 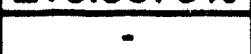 \\
\hline on temperature at & 274.5080 & 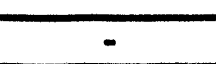 & 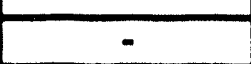 \\
\hline eat flux, kBtu/hr-ft2 & 101.0104 & 1 & $\pm 14119 \%$ \\
\hline Outer heat flux, kBtu/hr-ft2 & 100.9008 & $\theta$ & $\pm 1.5432 \%$ \\
\hline Hydraulic diameter, feet & 0.0390 & - & - \\
\hline TIN00001, inlet fluid temperature, $F$ & 87.1651 & 0.12664 & \pm 1.9002 \\
\hline TAF130136, outlet fluid temperature, $F$ & 237.8820 & 0.61390 & \pm 1.9189 \\
\hline TAF130048, outlet fluid temperature, $F$ & 252.5833 & 0.48068 & \pm 1.9223 \\
\hline TAF130224, outlet fluid temperature, $F$ & 232.0694 & 0.43451 & \pm 1.9176 \\
\hline TAF 130312 outlet fluid tem & 257.1989 & 0.56810 & \pm 1.9235 \\
\hline 001 , inlet pressure, psia & 40.0797 & 0.070664 & \pm 0.75666 \\
\hline PAB000316 inlet oressure osia & 40.3552 & 0.062595 & \pm 0.58871 \\
\hline PAB125136, outlet pressure, psia & 45.0459 & 0.079690 & \pm 0.59083 \\
\hline PAN000136, oressure droo. $\mathrm{HCO}$ & -133.6011 & 1.1662 & \pm 4.9313 \\
\hline PAN130136, press & -1.9651 & $\frac{1.0064}{1.5864}$ & \pm 0.87001 \\
\hline PFM00001, flow, \% & 1.5723 & 0.078930 & \pm 0.50002 \\
\hline He saturation pres & & & \\
\hline
\end{tabular}

\begin{tabular}{|c|c|c|c|}
\hline \multicolumn{4}{|c|}{ Table B2 } \\
\hline $\begin{array}{c}\text { Femperature, C } \\
\text { (F) }\end{array}$ & $\begin{array}{c}\text { Density [7] } \\
\mathrm{kg} / \mathrm{m}^{3}\end{array}$ & $\begin{array}{c}\text { Specific Heat [4] } \\
\text { J/kg-C }\end{array}$ & $\begin{array}{c}\text { Thermal } \\
\text { Conductivity [7] } \\
\text { W/m-C }\end{array}$ \\
\hline $30.65(87.17)$ & 994.91 & 4181.64 & 0.61873 \\
\hline $118.30(244.93)$ & 944.93 & 4244 & 0.68659 \\
\hline $134.73(274.51)$ & 931.63 & 4279 & 0.68842 \\
\hline
\end{tabular}

\section{Table B3}

Uncertainty Values for Velocity Prediction for Test Aug01 08

\begin{tabular}{|c|c|c|c|c|}
\hline Parameter & Value & Bias & Precision & Combined \\
\hline Area & $0.0150 \mathrm{ft}^{2}$ & $\pm 0.0002 \mathrm{ft}^{2}$ & - & $\pm 0.0002 \mathrm{ft}^{2}$ \\
\hline Pressure drop & $1.5723^{\mathrm{n}} \mathrm{H}_{2} \mathrm{O}$ & $\pm 0.5^{\mathrm{N}} \mathrm{H}_{2} \mathrm{O}$ & $0.25 \%$ rd & $\pm 0.50002^{\mathrm{n}} \mathrm{H}_{2} \mathrm{O}$ \\
\hline
\end{tabular}




\section{Appendix C}

Directory of Electronic Data Files by Disk Number 
DIRTCTORY TOR DATA DISK I

DATA FIL SIzE

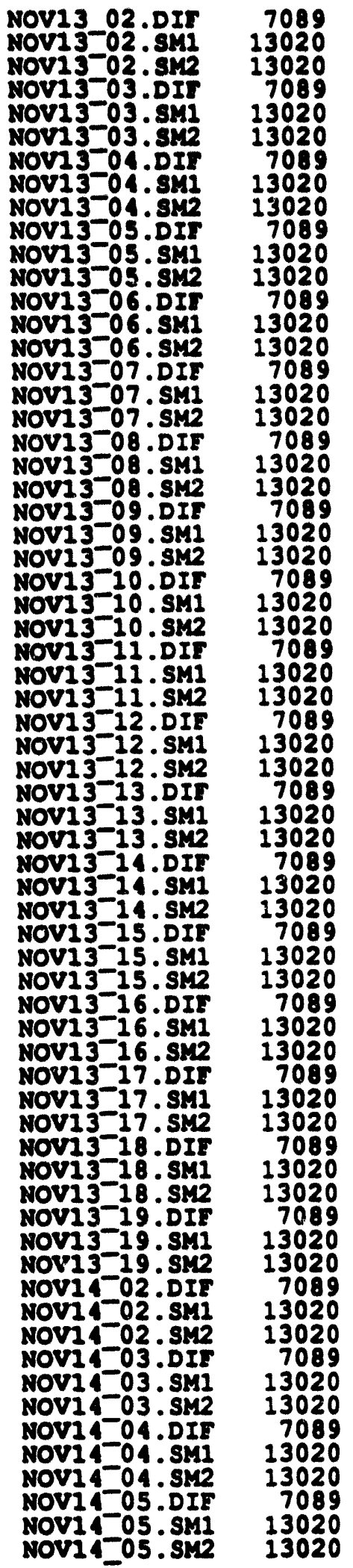




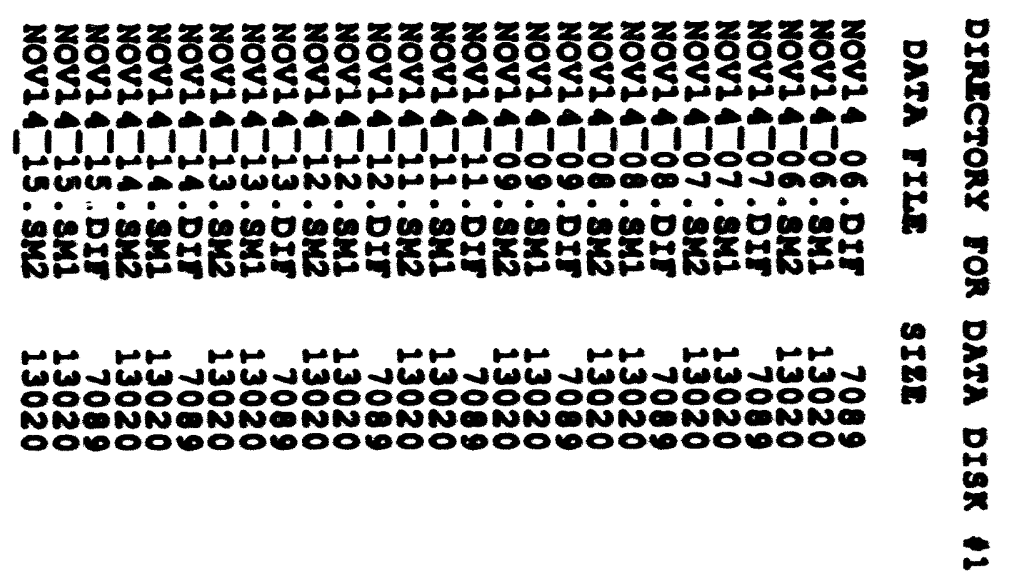


DIRzezony rOR DAxA DISK 12

Dagx rIs sIg:

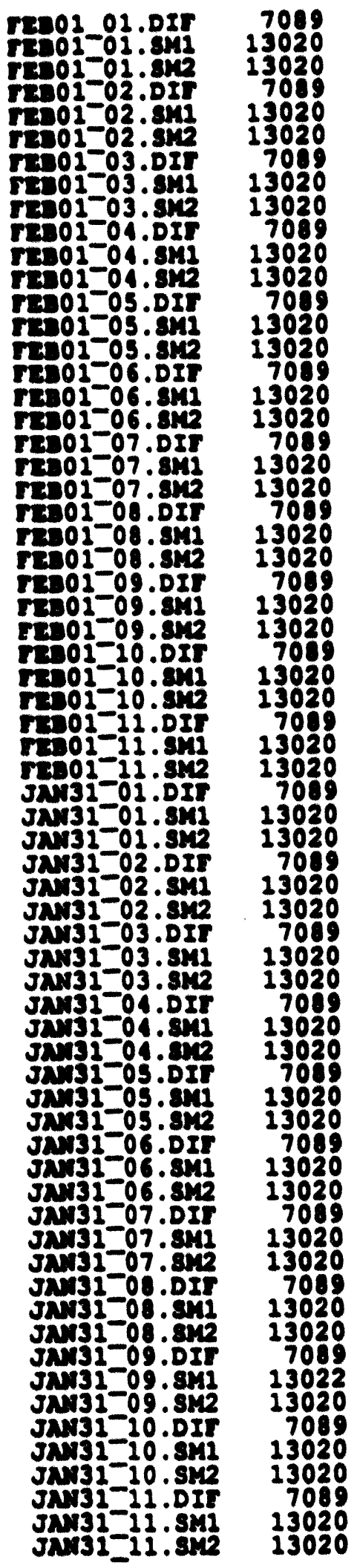




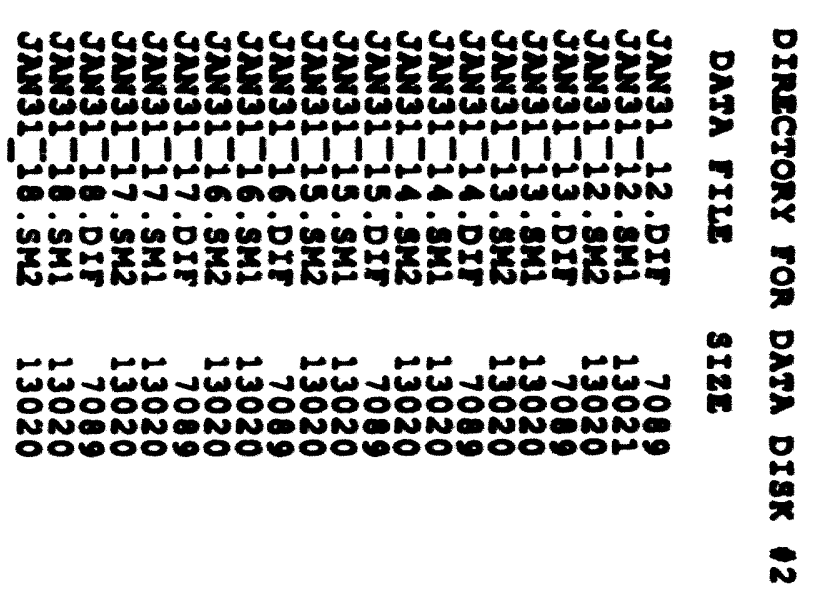




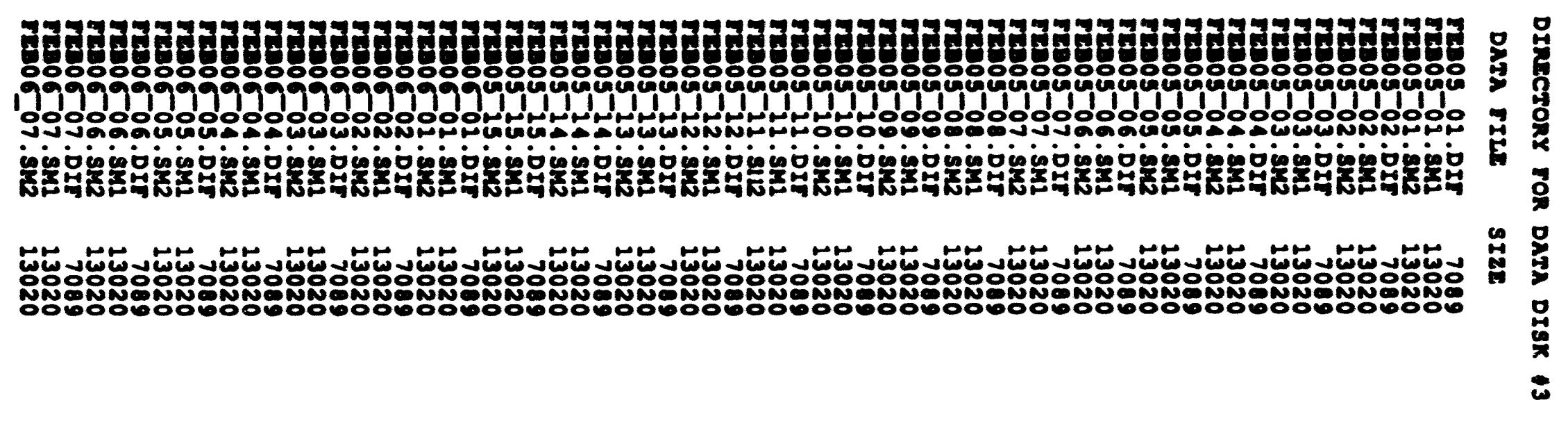




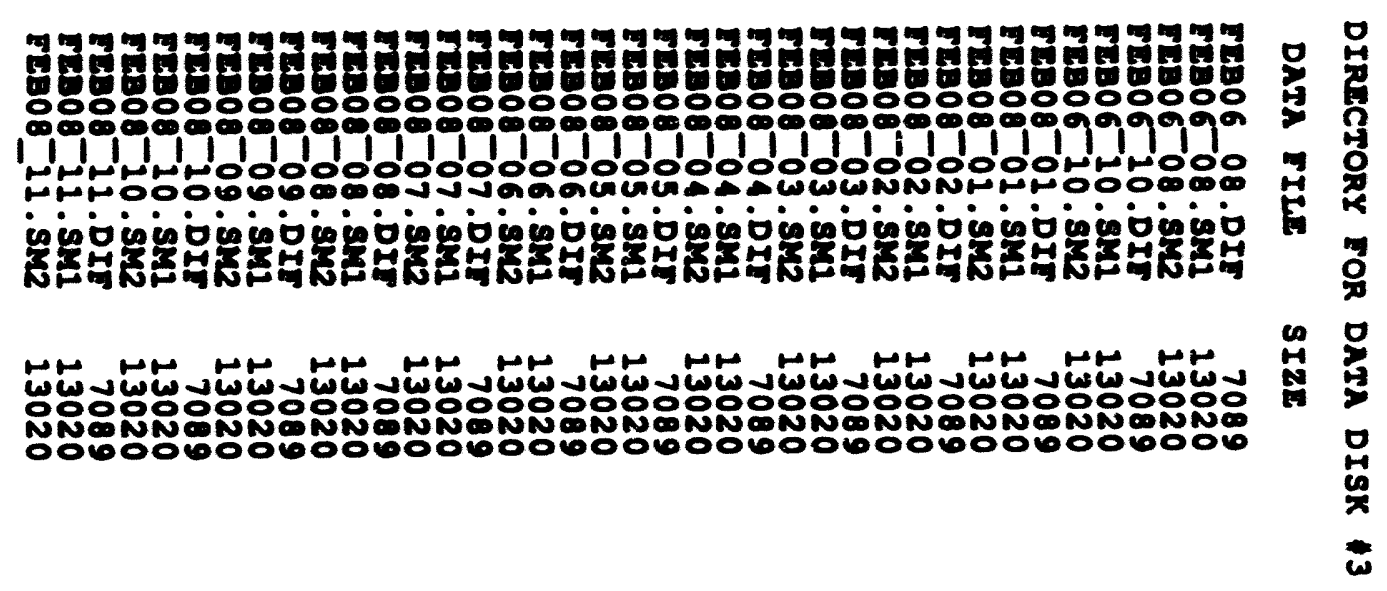




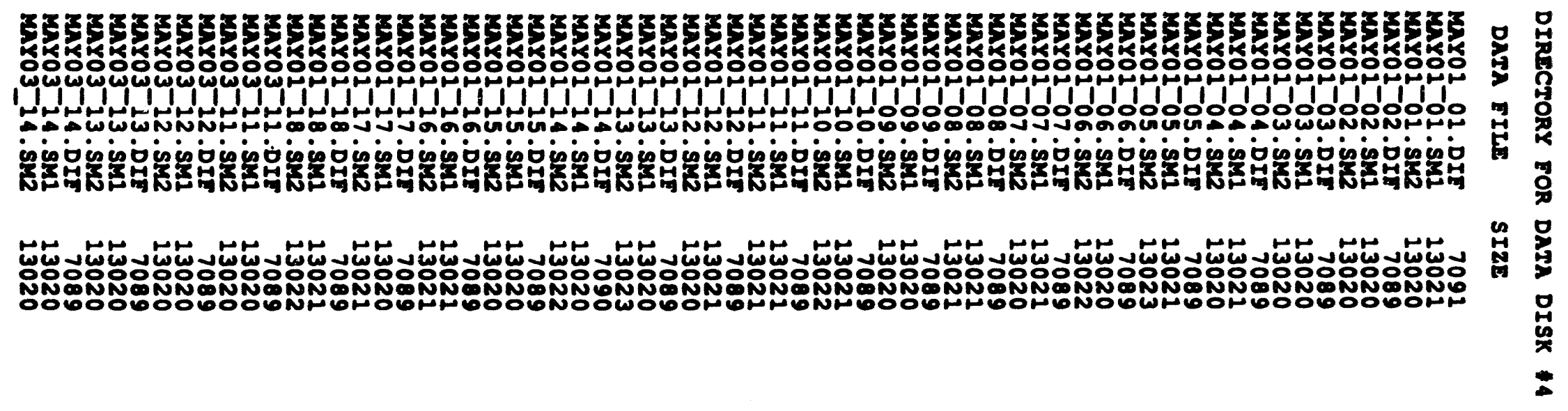


DIRECTORY FOR DATA DISK \#4

DATA EILE SIZE

\begin{tabular}{|c|}
\hline 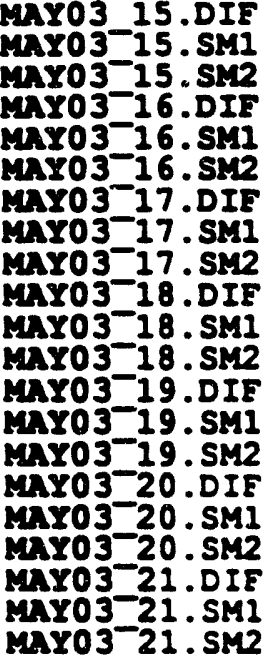 \\
\hline
\end{tabular}


DIRECTORY FOR DATA DISK $\$ 5$

DATA EIIE SIZE

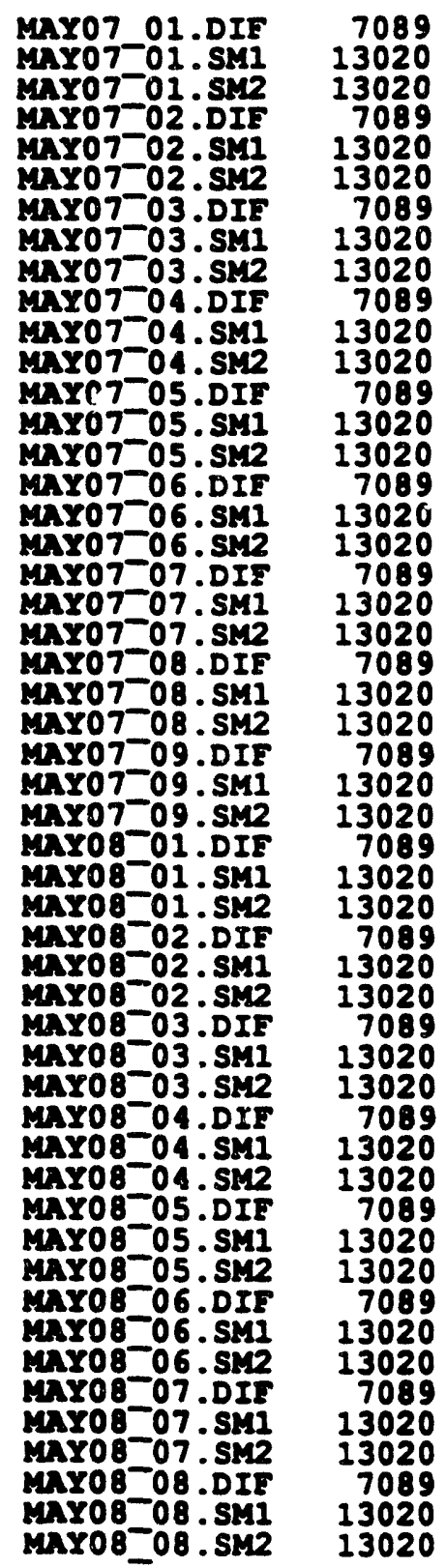




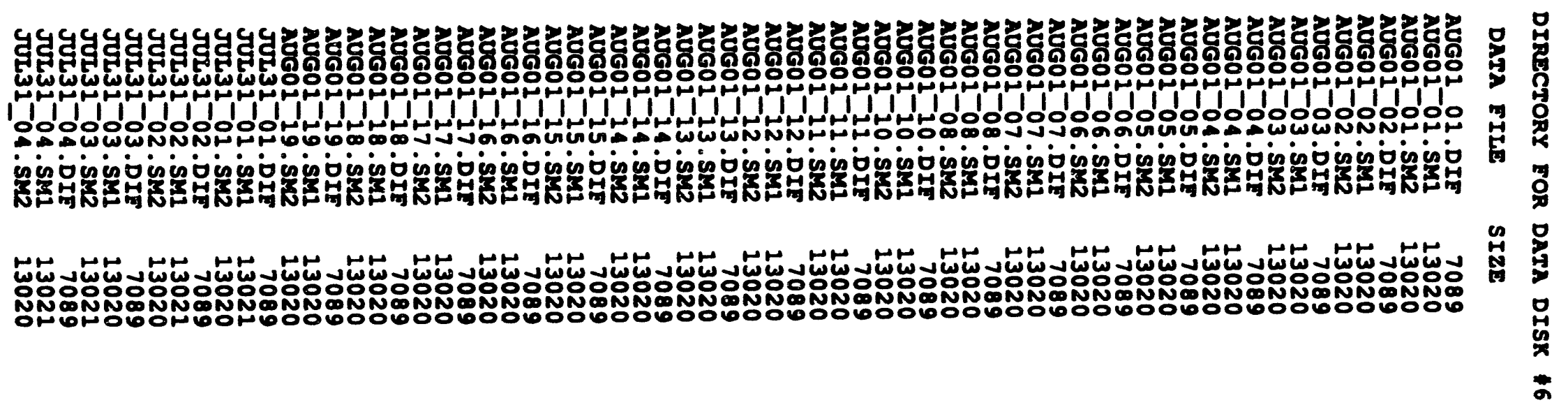




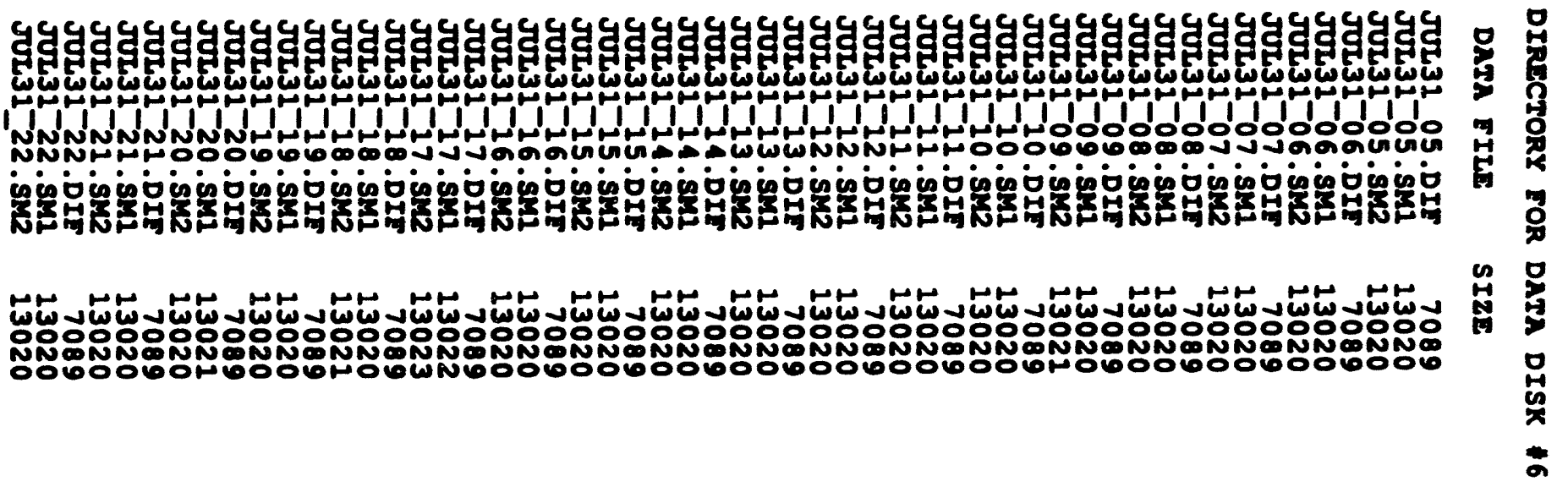




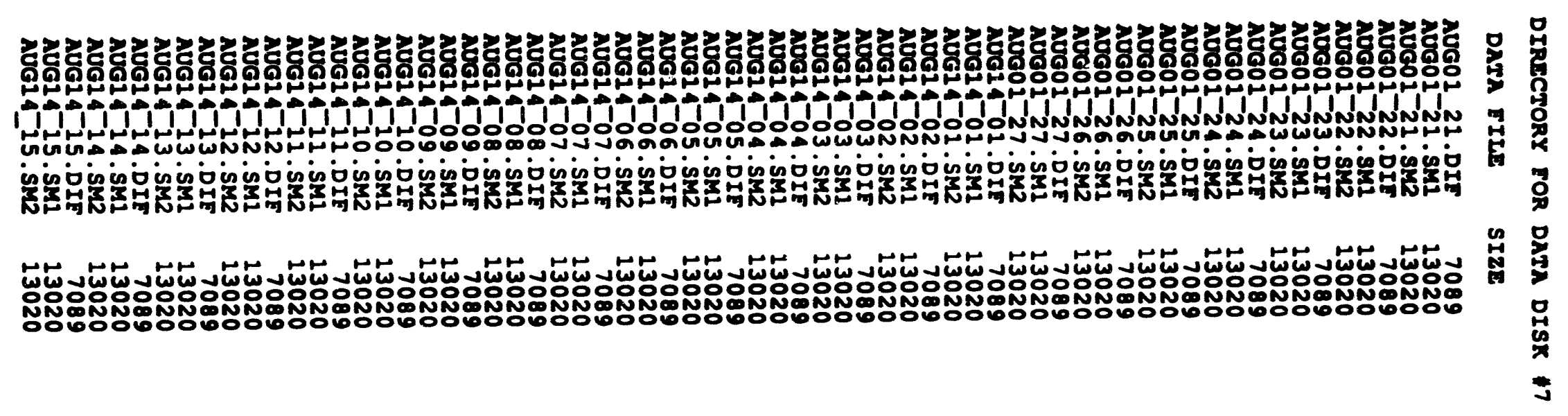

o 
DIRECTORY FOR DATA DISK 7

\begin{tabular}{|c|c|}
\hline & $3+2$ \\
\hline 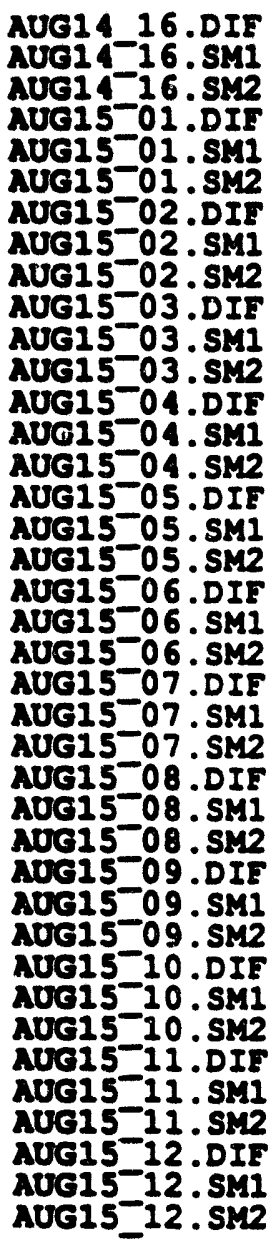 & \\
\hline
\end{tabular}




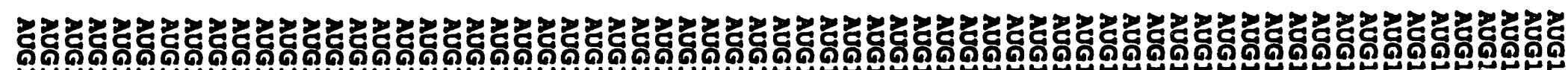

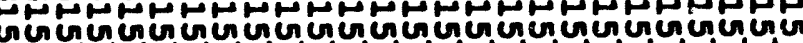
1yoy y y y y y y y.

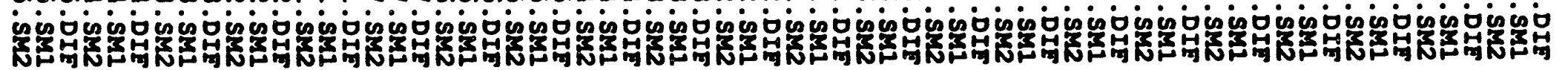

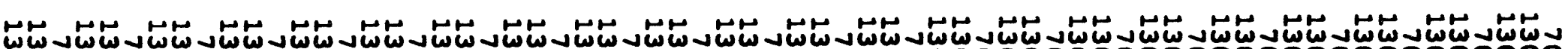
พั้ 
DIRECTORY FOR DATA DISK

DATA FILE SIZE

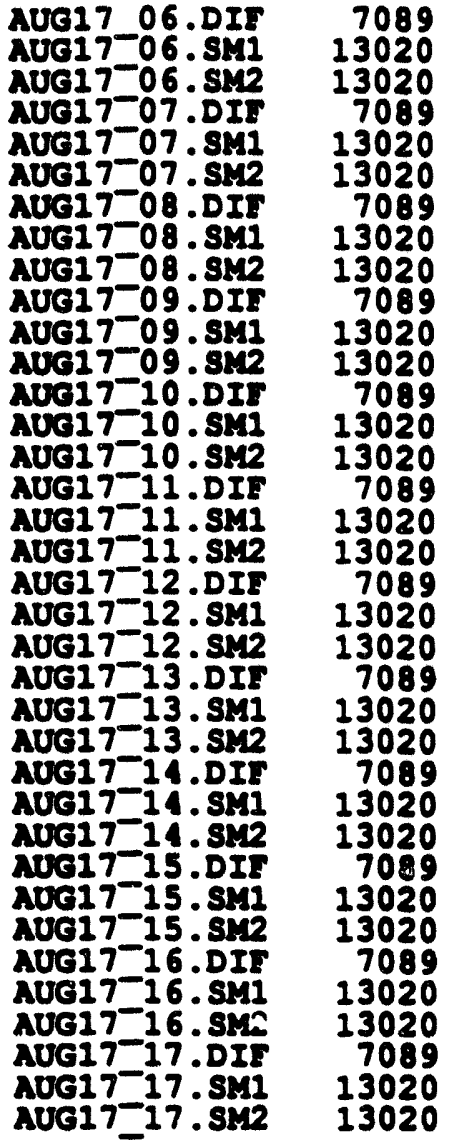




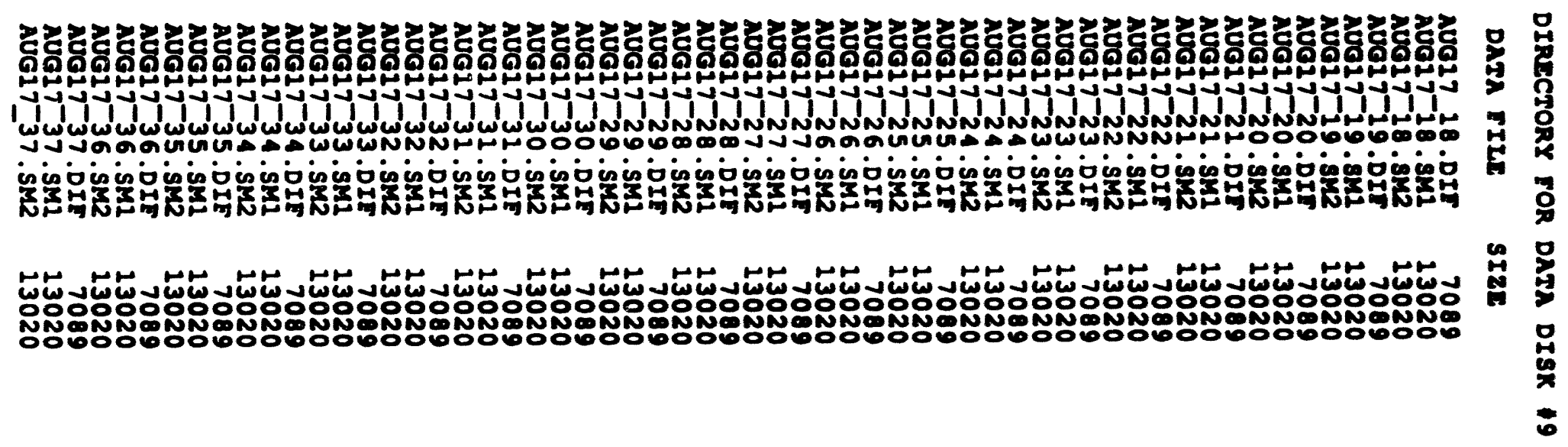


Appondix $\mathrm{D}$

Comparison of Printed and Electronic Data Files 


\begin{tabular}{|c|c|c|c|c|c|c|}
\hline $\begin{array}{l}\text { Book } \\
\text { Number }\end{array}$ & $\begin{array}{l}\text { Disk } \\
\text { Number }\end{array}$ & $\begin{array}{l}\text { Chapler } \\
\text { Number }\end{array}$ & $\begin{array}{l}\text { Fll } \\
\text { Number }\end{array}$ & $\begin{array}{l}\text { Column } \\
\text { Location }\end{array}$ & $\begin{array}{l}\text { Row } \\
\text { Lochtion }\end{array}$ & $\begin{array}{c}\text { Eook } 3 \text { or } 4 \\
\text { Det }\end{array}$ \\
\hline 3 & 1 & 1 & Nov14 02 & 4 & 160 & .0 .3997 \\
\hline$\frac{5}{3}$ & $\frac{1}{1}$ & $T$ & Nov14 03 & $\mathbf{5}$ & 20 & 0.16084 \\
\hline 3 & 1 & $T$ & Nov14 O4 & 4 & 97 & 5.2676 \\
\hline 3 & 1 & $T$ & Nov14 05 & 5 & 127 & $3.46810-03$ \\
\hline 3 & 1 & 1 & Nov14 06 & 2 & 63 & 2.0996 \\
\hline 3 & 1 & 1 & Novid 07 & 6 & 69 & $0.00000+00$ \\
\hline 3 & 1 & $T$ & Nov14 08 & 1 & 98 & PABO000136 \\
\hline 3 & $T$ & $T$ & Nov14 09 & 4 & 141 & 128.5323 \\
\hline 3 & 1 & 1 & Nov14 11 & 1 & 53 & TS1000001 \\
\hline 3 & $T$ & $T$ & Nov14 12 & 2 & 29 & 40.0646 \\
\hline 3 & $T$ & $T$ & Nov14 13 & 2 & 108 & -6.8652 \\
\hline 3 & $T$ & $T$ & Nov14 14 & 1 & 98 & PAB000136 \\
\hline 3 & 1 & 1 & Nov14 15 & 4 & 57 & 88.2431 \\
\hline 3 & 2 & 2 & Feb01 01 & 2 & 51 & 117.7159 \\
\hline 3 & 2 & 2 & Fabol 02 & 3 & 50 & 132.6199 \\
\hline 3 & 2 & 2 & $F a b 0103$ & 3 & 126 & -0.0098 \\
\hline 3 & 2 & 2 & Fabo1 04 & 4 & 81 & -18.1642 \\
\hline 3 & 2 & 2 & Fobo1 05 & 3 & 72 & 1.2451 \\
\hline 3 & 2 & 2 & Fob01 08 & 5 & 131 & 5.12686 .01 \\
\hline$\overline{3}$ & 2 & 2 & Fob01 07 & 5 & 4 & 5.32770 .01 \\
\hline 3 & 2 & 2 & $F 060108$ & 6 & 36 & $1.9087 \theta+00$ \\
\hline 3 & 2 & 2 & $F 060109$ & 6 & 65 & $0.00000+00$ \\
\hline 3 & 2 & 2 & Fob01 10 & 5 & 86 & 9.18440 .01 \\
\hline 3 & 2 & 2 & Fab01 11 & 8 & 12 & $1.92980+00$ \\
\hline 3 & 3 & 3 & Fob05 01 & 5 & 114 & $1.07639-01$ \\
\hline 3 & 3 & 3 & Fobos o? & 1 & 10 & TA0090136 \\
\hline 3 & 3 & 3 & $F 000503$ & 4 & 134 & 133.0568 \\
\hline 3 & 3 & 3 & Fob05 O4 & 4 & 130 & 130.4238 \\
\hline 3 & 3 & 3 & Fobos ob & 4 & 15 & 37.4317 \\
\hline 3 & 3 & 3 & $F 000506$ & 5 & 29 & $1.09800-01$ \\
\hline 3 & 3 & 3 & Feb05 07 & 5 & 124 & $3.58950-03$ \\
\hline 3 & 3 & 3 & Fob05 08 & 4 & 119 & 1292.3109 \\
\hline 3 & 3 & 3 & Fob05 09 & 4 & 158 & 107.6232 \\
\hline 3 & 3 & 3 & Fabo5 10 & 6 & 163 & $4.2055 e+00$ \\
\hline 3 & 3 & 3 & Fob05 11 & 3 & 52 & 155.2162 \\
\hline 3 & $\overline{3}$ & 3 & Fob05 12 & $\overline{3}$ & 150 & 107.1101 \\
\hline 3 & 3 & 3 & $F 000513$ & 1 & 113 & VPW000002 \\
\hline 3 & 3 & $\overline{3}$ & Fobos 14 & 2 & 49 & 161.6983 \\
\hline 3 & 3 & 3 & Fob05 15 & $T$ & 28 & TAT 125000 \\
\hline 3 & 3 & 4 & Fab06 01 & 1 & 57 & TAF02136 \\
\hline 3 & 3 & 4 & Fob06 02 & 3 & 149 & 95.0947 \\
\hline 3 & 3 & 4 & $F a b 0603$ & 2 & 68 & 0.7715 \\
\hline$\overline{3}$ & 3 & $\overline{4}$ & Fob06 04 & $\overline{3}$ & 79 & 1.2354 \\
\hline 3 & 3 & 4 & Fob06 05 & 1 & 61 & EMPTY \\
\hline 3 & 3 & 4 & Fobo6 06 & 3 & 150 & 107.7524 \\
\hline 3 & 3 & 4 & Fobo6 07 & 4 & 133 & 126.1641 \\
\hline 3 & 3 & 4 & $F 060608$ & 3 & 83 & -5.8099 \\
\hline 3 & 3 & 4 & $F 0606 \quad 10$ & 3 & 75 & 2.1631 \\
\hline 3 & 3 & 5 & Feb08 01 & 3 & 16 & 158.5175 \\
\hline 3 & 3 & 5 & Fab08 02 & 6 & 150 & $4.3662 \theta+00$ \\
\hline
\end{tabular}




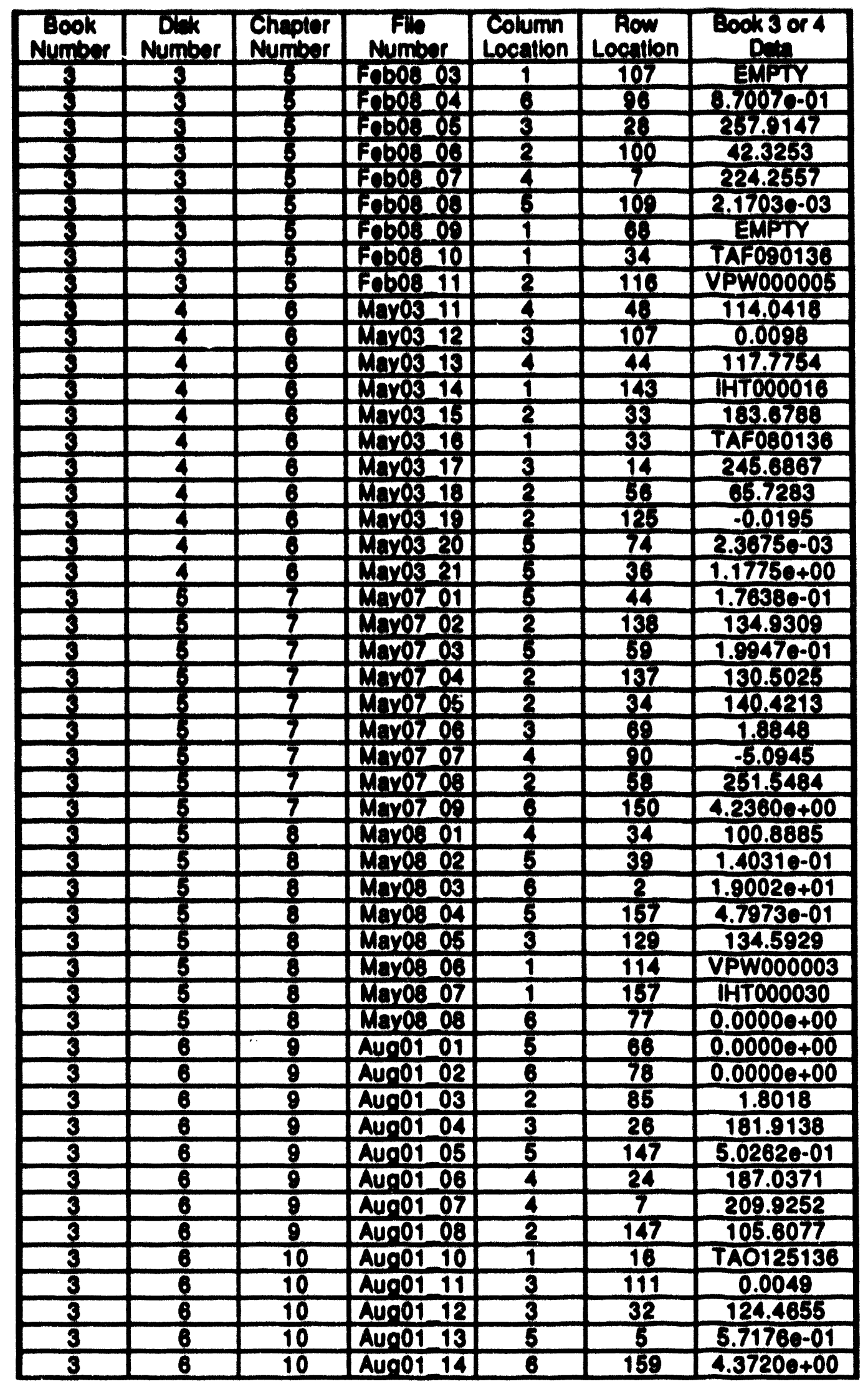




\begin{tabular}{|c|c|c|c|c|c|c|}
\hline $\begin{array}{l}\text { Eook } \\
\text { Number }\end{array}$ & $\begin{array}{c}\text { Dlak } \\
\text { Number }\end{array}$ & $\begin{array}{l}\text { Chapter } \\
\text { Number }\end{array}$ & $\begin{array}{l}\text { Flle } \\
\text { Number }\end{array}$ & $\begin{array}{l}\text { Column } \\
\text { Location }\end{array}$ & $\begin{array}{c}\text { Row } \\
\text { Location }\end{array}$ & $\begin{array}{c}\text { Book } 3 \text { or } 4 \\
\text { Doth }\end{array}$ \\
\hline 3 & 6 & 10 & Auo01 15 & 3 & 49 & 281.9731 \\
\hline 3 & 8 & 10 & Aup01 16 & 4 & 4 & 87.7484 \\
\hline 3 & 6 & 10 & Aupor 17 & 2 & 109 & 0.0000 \\
\hline 8 & 8 & 10 & Aunor 18 & 1 & 150 & IHTO00023 \\
\hline & 7 & 10 & Aup01 19 & 5 & 156 & $7.58560-01$ \\
\hline 3 & $=$ & 11 & Aun01 21 & 5 & 103 & 5.67220 .02 \\
\hline 3 & 7 & 11 & Aup01 22 & 2 & 21 & 154.8192 \\
\hline 3 & 7 & 11 & Aup01 23 & 2 & 90 & -6.1116 \\
\hline 3 & & 11 & Aup01 24 & 6 & 28 & $1.93140+00$ \\
\hline 3 & 7 & 11 & Aup01 25 & 2 & 133 & .1 .6226 \\
\hline 3 & 7 & 11 & Aug01 26 & 6 & 141 & $4.47920+00$ \\
\hline 3 & & 11 & Aup01 27 & 3 & 42 & 239.9919 \\
\hline 4 & 7 & 12 & Aunds 01 & 5 & 62 & $2.44840-03$ \\
\hline 4 & 7 & 12 & Auo15 02 & 4 & 80 & 36.1738 \\
\hline 4 & 7 & 12 & Aug15 03 & 1 & 143 & IHTO00016 \\
\hline 4 & 7 & 12 & Aug15 04 & 5 & 159 & $5.01860-01$ \\
\hline 4 & 7 & 12 & Aung15 05 & 1 & 123 & IPW000006 \\
\hline 4 & & 12 & Aug15 06 & 3 & 47 & 39.8352 \\
\hline 4 & 7 & 12 & Auso15 07 & 4 & 24 & 165.0095 \\
\hline 4 & & 12 & \begin{tabular}{|l|l|l|} 
Aup 15 & 08 \\
\end{tabular} & 6 & 68 & $0.00000+00$ \\
\hline 4 & & 12 & Aug15 09 & 6 & 48 & $1.92150+00$ \\
\hline 4 & 7 & 12 & Aunds 10 & 1 & 17 & TA0130136 \\
\hline 4 & 7 & 12 & Aug15 11 & 4 & 153 & 104.8008 \\
\hline 4 & 7 & 12 & Aug15 12 & $\overline{3}$ & 37 & 217.3546 \\
\hline 4 & 8 & 13 & Aug15 13 & 6 & 55 & $1.90000+00$ \\
\hline 4 & 8 & 13 & Aund15 14 & 4 & 9 & 34.2478 \\
\hline 4 & 8 & 13 & Aug15 15 & 1 & 94 & PAN120224 \\
\hline 4 & 8 & 13 & Aug15 16 & 4 & 32 & 164.1437 \\
\hline 4 & 8 & 13 & Aund5 21 & 3 & 76 & 1.7383 \\
\hline 4 & 8 & 13 & Aug15 22 & 4 & 83 & -4.1581 \\
\hline 4 & 8 & 13 & Auno15 23 & 4 & 85 & -0.8535 \\
\hline 4 & 8 & 13 & Aund5 24 & 4 & 29 & 255.1373 \\
\hline 4 & 8 & 13 & Auo15 25 & 4 & 89 & -1.4229 \\
\hline 4 & 8 & 13 & Aug15 26 & 2 & 118 & 1504.9567 \\
\hline 4 & 8 & 14 & Aug16 01 & 5 & 57 & $1.55750-01$ \\
\hline 4 & 8 & 14 & Auo16 02 & 6 & 122 & $2.83910+00$ \\
\hline 4 & 8 & 14 & Aup16 03 & 2 & 32 & 127.1168 \\
\hline 4 & 8 & 14 & Aung16 04 & 1 & 132 & IHTO00005 \\
\hline 4 & 8 & 14 & Aup16 05 & 6 & 84 & $8.70230-01$ \\
\hline 4 & 8 & 14 & Aug16 06 & 3 & 30 & 40.0646 \\
\hline 4 & 8 & 14 & Aug16 07 & 3 & 60 & 3.8770 \\
\hline 4 & 8 & 15 & Aug17 01 & 6 & 68 & $0.00000+00$ \\
\hline 4 & 8 & 15 & Auo17 02 & 5 & 62 & $3.2554 \theta-03$ \\
\hline 4 & 8 & 15 & Aug17 03 & 5 & 152 & $4.51700-01$ \\
\hline 4 & 8 & 15 & Aug17 04 & 5 & 34 & $2.51080-01$ \\
\hline 4 & 8 & 15 & Aus17 05 & 5 & 157 & $7.04330-01$ \\
\hline 4 & 8 & 15 & Aug17 06 & 1 & 87 & PAN110136 \\
\hline 4 & 8 & 15 & Auo17 07 & 3 & 12 & 255.8337 \\
\hline 4 & 8 & 15 & \begin{tabular}{|l|l|l} 
Aug17 & 08 \\
\end{tabular} & 6 & 3 & $1.9002 \theta+00$ \\
\hline 4 & 8 & 16 & \begin{tabular}{|ll} 
Aus 1709 \\
\end{tabular} & 2 & 125 & -0.0195 \\
\hline 4 & 8 & 16 & Aug17 10 & 2 & 124 & -0.0293 \\
\hline 4 & 8 & 16 & Aug17 11 & 4 & 154 & 156.2597 \\
\hline
\end{tabular}




\begin{tabular}{|c|c|c|c|c|c|c|}
\hline $\begin{array}{c}\text { Book } \\
\text { Number }\end{array}$ & $\begin{array}{c}\text { Disk } \\
\text { Number }\end{array}$ & $\begin{array}{l}\text { Chapter } \\
\text { Number }\end{array}$ & $\begin{array}{c}\text { File } \\
\text { Number }\end{array}$ & $\begin{array}{l}\text { Column } \\
\text { Location }\end{array}$ & $\begin{array}{c}\text { Row } \\
\text { Location }\end{array}$ & $\begin{array}{c}\text { Book } 3 \text { or } 4 \\
\text { Deta }\end{array}$ \\
\hline 4 & 2 & 20 & $\operatorname{Jan} 3108$ & 2 & 109 & 0.0000 \\
\hline 4 & 2 & 20 & $\operatorname{Jan} 3109$ & 5 & 108 & $2.6610 \theta-01$ \\
\hline 4 & 2 & 20 & $\operatorname{Jan} 31 \quad 10$ & 1 & 60 & EMPTY \\
\hline 4 & 2 & 20 & $\operatorname{Jan} 3111$ & 4 & 158 & 0.0833 \\
\hline 4 & 2 & 20 & $\operatorname{Jan} 31 \quad 12$ & 4 & 120 & -0.9048 \\
\hline$\overline{4}$ & $\overline{2}$ & 20 & $\operatorname{Jan} 3113$ & $\overline{3}$ & 91 & -5.6009 \\
\hline 4 & 2 & 20 & $\operatorname{Jan} 31 \quad 14$ & $\overline{2}$ & 66 & 0.3613 \\
\hline 4 & 2 & 20 & Jan31 15 & 4 & 119 & -4.4973 \\
\hline 4 & 2 & 20 & $\operatorname{Jan} 3116$ & 2 & 81 & -20.5650 \\
\hline$\overline{4}$ & 2 & 20 & $\operatorname{Jan} 3117$ & 1 & 107 & EMPTY \\
\hline 4 & 2 & 20 & $\operatorname{Jan} 3118$ & 4 & 10 & 87.5365 \\
\hline 4 & $\overline{0}$ & 20 & Jan31 19 & 6 & 147 & $4.1000 \theta+00$ \\
\hline 4 & 4 & 20 & May01 01 & 6 & 68 & $0.0000 \theta+00$ \\
\hline 4 & 4 & 20 & May01 02 & 6 & 27 & $1.9002 \theta+00$ \\
\hline 4 & 4 & 20 & May01 03 & 5 & 91 & $1.36270-01$ \\
\hline 4 & 4 & 20 & May01 04 & 5 & 96 & $1.8238 \theta-01$ \\
\hline 4 & 4 & 20 & May01 05 & 3 & 85 & 23.7202 \\
\hline 4 & 4 & 20 & May01 06 & 4 & 31 & 86.6870 \\
\hline 4 & 4 & 20 & May01 07 & 3 & 152 & 0.1352 \\
\hline$\overline{4}$ & 4 & 20 & May01 08 & 4 & 154 & -0.0418 \\
\hline 4 & 4 & 20 & May01 09 & 3 & 122 & -0.0751 \\
\hline 4 & 4 & 20 & May01 10 & 1 & 41 & TAF130136 \\
\hline 4 & 4 & 20 & May01 11 & 1 & 124 & EMPTY \\
\hline 4 & 4 & 20 & May01 12 & 3 & 14 & 87.3251 \\
\hline 4 & 4 & 20 & May01 13 & 4 & 117 & -0.0224 \\
\hline 4 & 4 & 20 & May01 14 & 3 & 80 & -16.6920 \\
\hline 4 & 4 & 20 & May01 15 & 5. & 155 & $1.1334 \theta-01$ \\
\hline 4 & 4 & 20 & May01 16 & 5 & 2 & $2.1194 \theta-01$ \\
\hline$\overline{4}$ & 4 & 20 & May01 17 & 6 & 23 & $1.9002 \theta+00$ \\
\hline 4 & 4 & 20 & May01 18 & 2 & 93 & 41.9721 \\
\hline 4 & 6 & 20 & Jul31 01 & 5 & 89 & $1.0107 e-01$ \\
\hline 4 & 6 & 20 & Jul31 02 & 1 & 21 & TA0130224 \\
\hline 4 & 6 & 20 & \begin{tabular}{|l|l}
$J u l 31$ & 03 \\
\end{tabular} & 3 & 99 & 30.6266 \\
\hline 4 & 6 & 20 & Jul31 04 & 4 & 76 & 0.5569 \\
\hline 4 & 6 & 20 & Jul31 05 & 2 & 22 & 85.8685 \\
\hline 4 & 6 & 20 & Jul31 06 & 4 & 75 & 0.5371 \\
\hline 4 & 6 & 20 & Jul31 07 & 4 & 146 & -0.1297 \\
\hline 4 & 6 & 20 & Jul31 08 & 3 & 18 & 74.0284 \\
\hline 4 & 6 & 20 & Jul31 09 & 1 & 117 & VPW000006 \\
\hline 4 & 6 & 20 & Jul31 10 & 3 & 21 & 87.3196 \\
\hline 4 & 6 & 20 & Jul31 11 & 4 & 107 & 0.0027 \\
\hline 4 & 6 & 20 & Jul31 12 & 5 & 25 & $1.95730-01$ \\
\hline 4 & 6 & 20 & Jul31 13 & 5 & 85 & $4.7782 \theta-02$ \\
\hline 4 & 6 & 20 & Jul31 14 & 5 & 44 & $2.3607 e-01$ \\
\hline 4 & 6 & 20 & Jul31 15 & 2 & 86 & -4.5255 \\
\hline 4 & 6 & 20 & Jul31 16 & 5 & 119 & $1.0839 \theta+00$ \\
\hline 4 & 6 & 20 & \begin{tabular}{|l|l|} 
Jul31 17 \\
\end{tabular} & 4 & 129 & -0.0035 \\
\hline 4 & 6 & 20 & Jul31 18 & 5 & 136 & $7.9017 \theta-02$ \\
\hline 4 & 6 & 20 & Jul31 19 & 3 & 86 & 0.0522 \\
\hline 4 & 6 & 20 & Jul31 20 & 6 & 89 & $8.7001 \theta-01$ \\
\hline 4 & 6 & 20 & Jul31 21 & 4 & 160 & -0.0024 \\
\hline 4 & 6 & 20 & Jul31 22 & 2 & 92 & -7.4473 \\
\hline
\end{tabular}



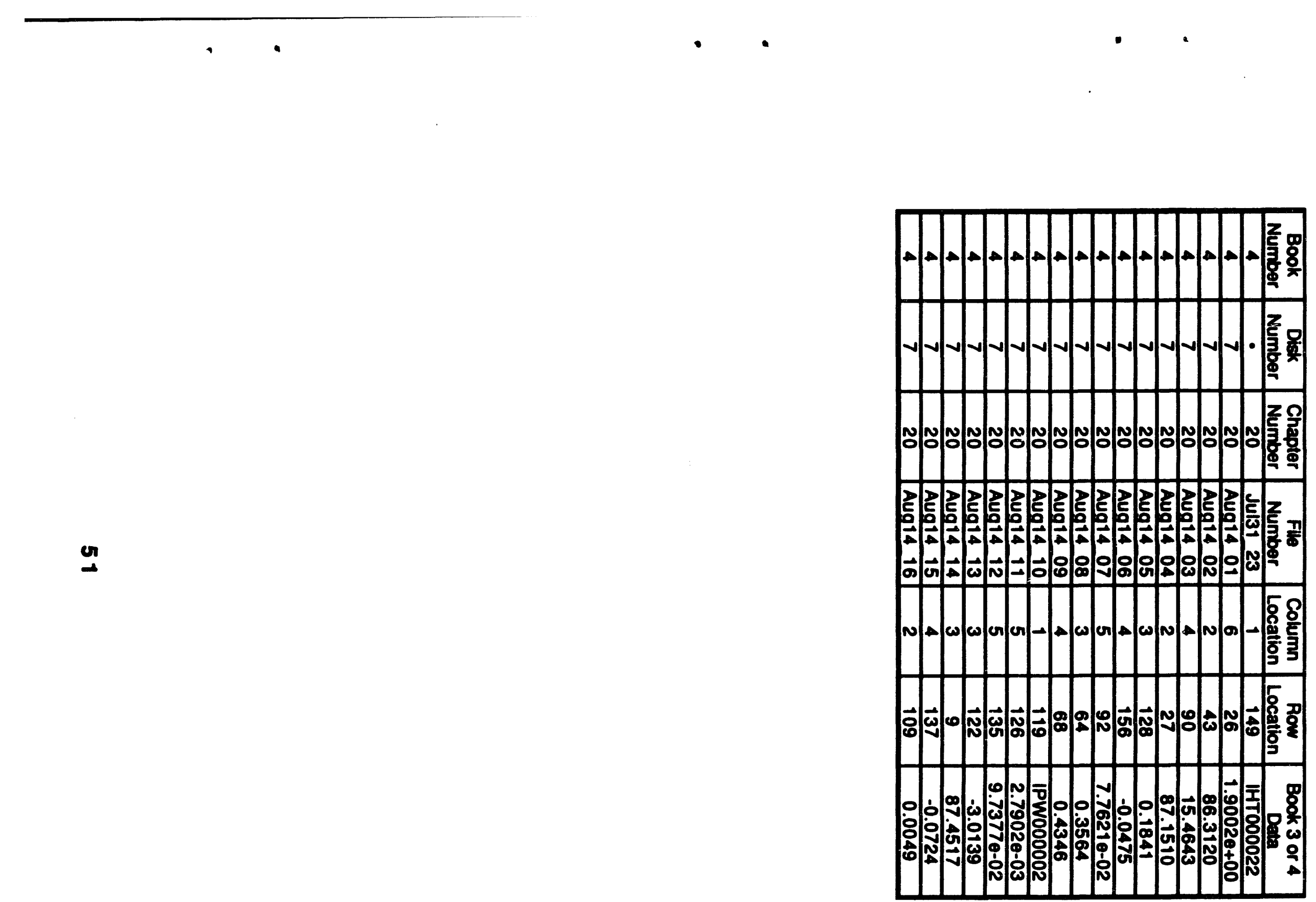

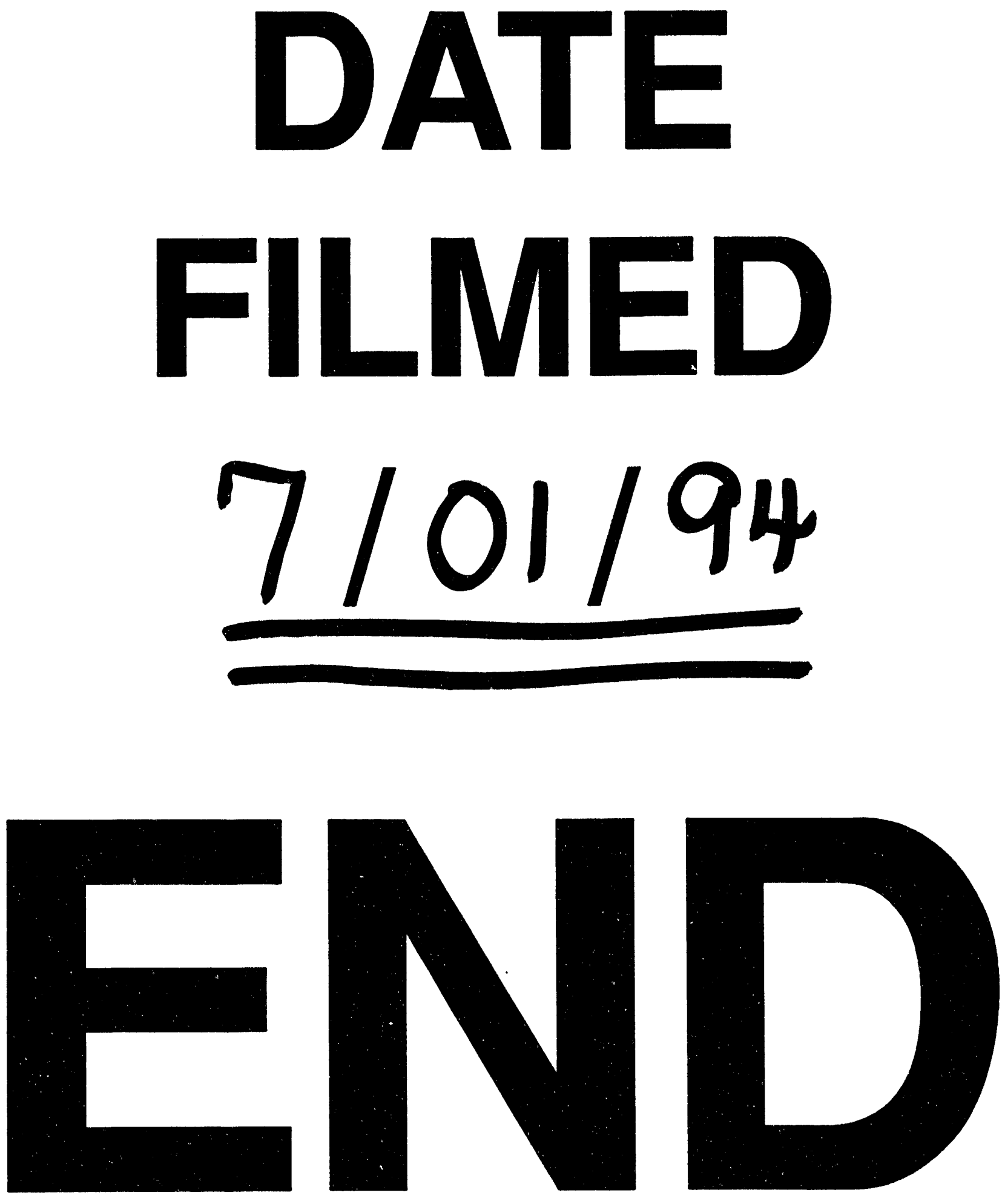
